\title{
Potential health risk and levels of heavy metals in water resources of lead-zinc mining communities of Abakaliki, southeast Nigeria
}

\author{
Philip Njoku Obasi ${ }^{1}$ (D) $\cdot$ Bennard Benedict Akudinobi ${ }^{2}$
}

Received: 14 December 2018 / Accepted: 13 May 2020 / Published online: 7 July 2020

(c) The Author(s) 2020

\begin{abstract}
Heavy metals are potential health risk, especially in mining sites where they deteriorate from sulfide-rich ore bodies. Lead, cadmium, arsenic and mercury are very carcinogenic, while others are toxic. The assessment of the levels of these metals in water resources of the lead-zinc mining communities of Enyigba, Mkpuma Akpatakpa, Ameka, Amorie, Amanchara and Alibaruhu was carried out, and the potential health risk has been investigated. These areas make up the main mining communities of Abakaliki, where active and abandoned mines are located. One hundred and six water samples were analyzed in two seasons using atomic absorption spectrophotometric and ultra-violet/visible spectroscopy. Result indicates levels of $\mathrm{Pb}^{2+}>\mathrm{Hg}^{2+}>\mathrm{As}^{2+}>\mathrm{Cd}^{2+}>\mathrm{Mn}^{2+}>\mathrm{Ag}^{2+}>\mathrm{Se}^{2+}>\mathrm{Ni}^{2+}>\mathrm{Cr}^{2+}>\mathrm{Cu}^{2+}$ in water sources. High levels of $\mathrm{Mn}^{2+}(63.45 \mathrm{mg} / \mathrm{L})$, $\mathrm{Pb}^{2+}(11.42 \mathrm{mg} / \mathrm{L}), \mathrm{Cr}^{3+}(14.60 \mathrm{mg} / \mathrm{L}), \mathrm{Ni}^{2+}(1.260), \mathrm{Cd}^{2+}(15.67 \mathrm{mg} / \mathrm{L}), \mathrm{Ag}^{+}(6.06 \mathrm{mg} / \mathrm{L}), \mathrm{Hg}^{2+}(2.60 \mathrm{mg} / \mathrm{L}), \mathrm{As}(4.13 \mathrm{mg} / \mathrm{L})$, $\mathrm{Se}^{2+}(2.68 \mathrm{mg} / \mathrm{L}), \mathrm{Zn}^{2+}(10.53 \mathrm{mg} / \mathrm{L})$ and $\mathrm{Co}^{2+}(0.9 \mathrm{mg} / \mathrm{L})$ above the WHO recommended standard for drinking water were observed. Only $\mathrm{Cu}^{2+}$ recorded safe concentrations in $100 \%$ samples analyzed. Levels of associated metals including $\mathrm{Pb}^{2+}$, As, $\mathrm{Hg}^{2+}, \mathrm{Se}^{2+}$ and $\mathrm{Cd}^{2+}$ are higher in groundwater especially in areas close to the active mines; this is due to mineralization in the area. Seasonal analysis shows a decreased concentration of chemical constituents in the rainy season relative to the dry season. Potential health risk is associated with accumulation of toxic heavy metals in tissues including Parkinson disease, arsenicosis, acrodynia, selenoises, Alzheimer's disease, hair loss, mental imbalance and abortion in women abound in the areas. Alternative water supply sources and sensitization on the potential health risk are highly advocated in these communities.
\end{abstract}

Keywords Heavy metals $\cdot$ Mining $\cdot$ Water pollution $\cdot$ Mine waste $\cdot$ Health impact

\section{Introduction}

Mining adversely affects the environment by inducing loss of biodiversity, soil erosion and contamination of surface water, groundwater and soil. It can also trigger the formation of sinkholes Hartman (1992). The leakage of chemicals from mining sites can also have detrimental effects on the health of the population living at or around the mining site. This has often led to water resources pollution which is a major challenge facing many developing countries of the world (U.S. Bureau of Mines 1994). This is because mine wastes

Philip Njoku Obasi

obasiphilip26@gmail.com; philip.njoku@ebsu.edu.ng

1 Department of Geology, Ebonyi State University, Abakaliki, Nigeria

2 Department of Geological Sciences, Nnamdi Azikiwe University, Awka, Nigeria generate acid mine drainage (AMD) which contains high amount of sulfide bearing components and can migrate offsite Hakkou et al. (2008a), Khalil et al. (2013), Obiora et al. (2018), Moye et al. (2017), Obasi and Akudinobi (2015). Sulfide ores, including galena, are composed of heavy metal components especially lead, mercury, copper, manganese, zinc, nickel, cobalt, arsenic, selenium, molybdenum, chromium, silver and vanadium (El Amari et al. 2014; Davies et al. 2005). Some heavy metals are either essential nutrient (cobalt and zinc) or relatively harmless such as silver. However, others like cadmium, mercury and lead are highly poisonous.

Hakkou et al. (2008a, b), El Amari et al. (2014), Moye et al. (2017), Owor et al. (2007), Khan et al. (2008, 2010), Moreno-Jimenez et al. (2009), Martinez-Martinez et al. (2013), Musah et al. (2013), Obiora et al. (2016, 2018) and Obasi and Akudinobi (2019a, b) have reported high concentration of heavy metals in different mining areas in Africa 
and the world over. Hakkou et al. (2008a, b) and El Amari et al. (2014) showed that the abandoned pyrrhotite mine in Kettara, Morocco, contains more than 3 million tons of mine wastes deposited in the environment without protection. The impact of AMD and geochemical assessment of soil/water in the Kettara mine environment have been described by Cidu et al. (2011) and Equeenuddin et al. (2010). Buzatu et al. (2016), Han et al. (2017) and Blowes et al. (2003) worked on the geochemical and eco-toxicological characteristics of stream water and groundwater of the Kettara mines in Morocco. Obiora et al. $(2016,2018)$ showed contamination of soils and potable water supply sources, respectively, with heavy metals and potentially harmful elements in the lead-zinc mining communities of Enyigba, Southeastern Nigeria. High concentrations of heavy metals including $\mathrm{Cu}, \mathrm{Co}, \mathrm{Ni}, \mathrm{Pb}$ and $\mathrm{As}$ have been reported in River Nyamwamba near the copper mine in Kilembe, Western Uganda; Abraham and Susan (2017), while Zhiyuan et al. (2014) also reviewed the pollution of heavy metals in soils in China and observed high concentrations. Alexakis (2016) investigated human health risk assessment associated with $\mathrm{Co}, \mathrm{Cr}, \mathrm{Mn}$, $\mathrm{Ni}$ and $\mathrm{V}$ in agricultural soils from a Mediterranean site and Ayandiran et al. (2014), Ayandiran and Dahunsi (2016), demonstrated that apart from mines and mining activities, microorganisms and bitumen can pollute surface water sources.

Zhao et al. (2008b, 2010) have demonstrated extensively that the dissolved metal front from mines may become unstable when it propagates in the soil/rock. The dissolved heavy metals can be transported in the soil/rock through pore-water advection, convection and solute diffusion/dispersion, and can contaminate both the land and the groundwater at the mine site Zhao et al. (2004, 2007, 2008a), Gamvroula et al. (2013). Yuosefi et al. (2017) emphasized that public health is at risk from physical and chemical contaminants in the drinking water which may have immediate health consequences. These contaminants often emanate from both natural and anthropogenic sources Todd (1980), Freeze and Cherry (1976). Natural sources may result from the host rocks (depending on the geology of the area), volcanic activities and chemical evolution of hydrochemical facies, while anthropogenic sources often emanate from the challenges of waste disposal linked to human activities, including urbanization, industrialization, mining, municipal and domestic activities, among others ATSDR (2007), Obasi and Akudinobi (2015).

Mineralization of ore deposits including galena, siderite, sphalerite and chalcopyrite Kogbe (1976), Obage (2009) is evident in the Abakaliki area of the Lower Benue Trough. Indiscriminate and illegal mining with the consequent random citing of mines and waste dumps, and unplanned disposal of gangues is obvious in the area Obasi and Akudinobi (2019a). Heavy metal effluents from the weathering of the mineral deposits may have adverse consequences on soil and water quality due to soil-water interaction Obasi and Akudinobi (2019b), Shuai-Long et al. (2013), Mohammad et al. (2010). Zhiyuan et al. (2014) and Koki et al. (2015) stated that apart from the challenges to sustainable water quality, pollutants and contaminants from mining sources constitute a major threat to human health, aquatic lives, land use and agriculture and other aspects of ecosystem imbalance. It is against this background that an investigation on the levels and potential health risk of these metals in the mining areas of Abakaliki is carried out. This study includes rural communities: Enyigba, Ameka, Amorie, Alibaruhu, Mkpuma Akpatakpa and Amanchara, where active and abandoned mines are located. This study is necessary and timely as a social interactive survey in the area indicates that more than $70 \%$ of these rural inhabitants depend on impounded water in abandoned mine ponds and unprotected stream channels for their domestic uses. It is also necessary that geochemically anomalous areas be detected to indicate the likely impact on the health of these uninformed rural dwellers. This study will provide valuable information on the levels and associated health risk of these heavy metals in the areas. This may likely constitute a vital planning tool to rural water supply and health safety regulatory agencies.

\section{Physiography and geology}

The study area is bounded by longitudes $8^{\circ} 00^{\prime} \mathrm{E}$ and $8^{\circ} 12^{\prime} \mathrm{E}$ and latitudes $6^{\circ} 05^{\prime} \mathrm{N}$ and $6^{\circ} 34^{\prime} \mathrm{N}$. It extends from Amanchara in the north to Ameka in the south and Izzi and Ngbo communities in the east and west, respectively, covering a total area of about $794.2 \mathrm{~km}^{2}$. It is part of the tropical hinterland climate Iloeje (1979) with average monthly rainfall of about $222 \mathrm{~mm}$, and mean annual temperature of about $29^{\circ} \mathrm{C}$. The vegetation cover is composed of very dense trees and undergrowth of creepers. These trees are mostly tall, with buttress roots. However, consistent farming in the area has left some parts of the land bare, cultivated or fallowed. Regionally, the area lies within the elongate intracontinental Cretaceous basin (about $1000 \mathrm{~km}$ in length), stretching in a NE-SW direction and resting unconformably upon the Precambrian Basement rocks known as the Benue Trough Burke et al. (1972); Nwachukwu (1975) (Fig. 2). It extends from the Gulf of Guinea to the Chad basin, and is thought to have been formed by the "Y"-Shaped triple-R Junction ridge system that initiated the breaking up and separation of the AfroBrazilian plates in the Early Cretaceous, Burke et al. (1972). The area is, however, underlain by the Asu River Group, which is the product of the earliest documented marine transgression in Nigeria, Nwajide (2013). This marine transgression occurred during the 
middle Albian and was limited to the Benue valley and southeastern Nigeria where the Asu River Group sediments as well as the Abakaliki Shales were deposited in moderately deep marine waters, Kogbe (1976). The Asu River Group consists largely of olive-brown sandy shales, fine grained micaceous sandstones and micaceous mudstones. Bluish-gray or olive-brown shales, which weather to a rusty brown color, are also present. The sequence is poorly fossiliferous, though there are occasional outcrops of thin shelly limestone. Locally, these shales differ in their physical characteristics. Some are fissile while other are indurated.

Hence, the designation into three different units: A, B and C. Igneous intrusions were also encountered in the area at Ndiechi, Abakaliki and Ezzagu (Fig. 1).

\section{Methodology}

\section{Sample Collection and preparation}

A total of one hundred and six (106) water samples comprising sixty-five (65) surface water and forty-one (41) groundwater were collected systematically on daily basis for the investigation (Fig. 1). Surface water sources considered include active and abandoned mine pits, rivers, streams and lakes, while groundwater sources include shallow wells (hand dug wells and hand pump wells). These samples were collected in the pre-monsoon and post-monsoon seasons. The water samples from all observation wells and surface water sources were stored in a plastic 1-liter container for detailed chemical analysis. These containers were washed thoroughly with distilled water and dried before being filled with the water samples.

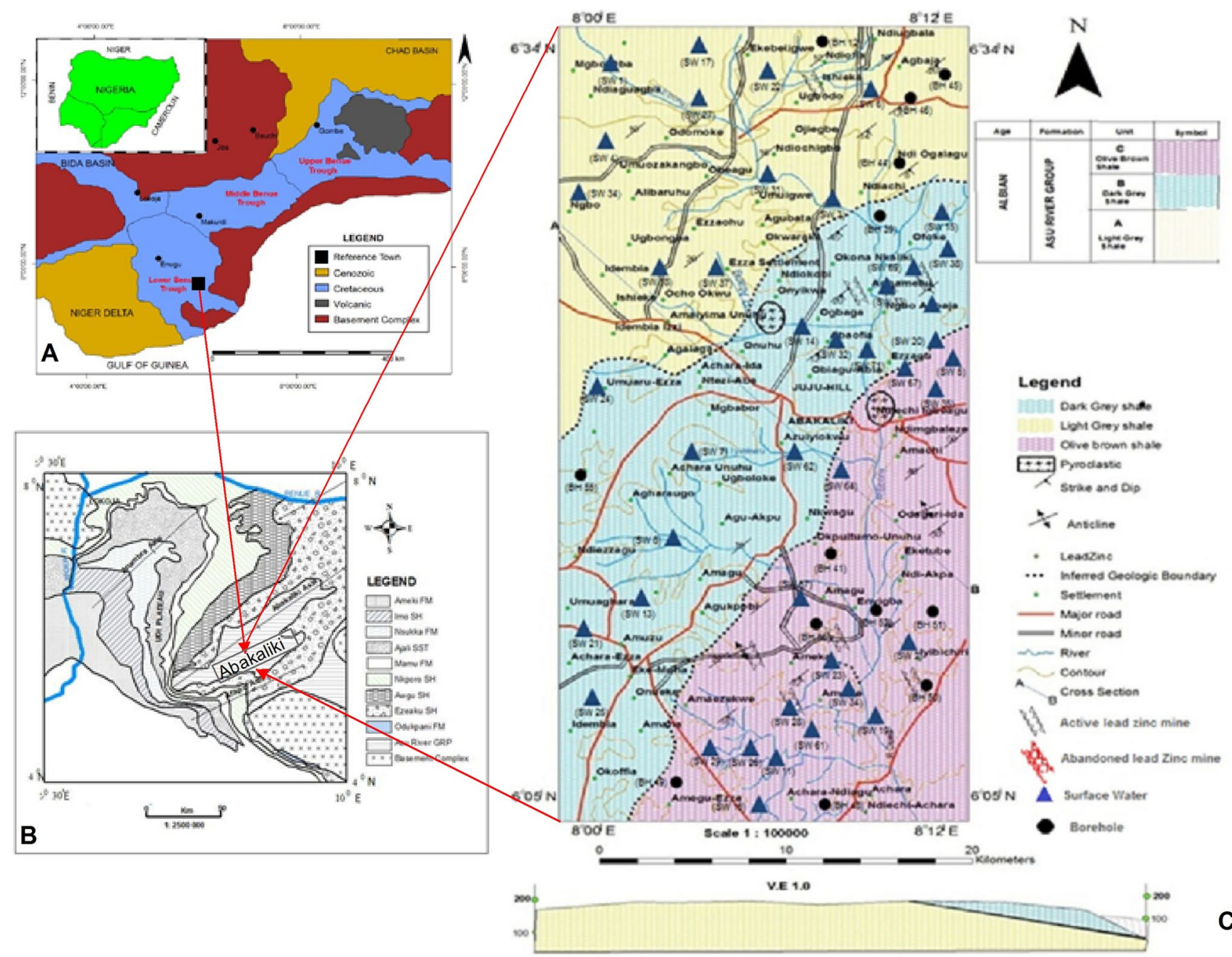

Fig. 1 a Geologic map of the Lower Benue Trough (LBT) Zarborski (1998), b stratigraphic settings of the LBT (modified from Nwajide 2013), c geological map the study area showing dominant rock types and sample locations 
To obtain a composite sample, they were collected after the well was subjected to pumping for 5-10 $\mathrm{min}$ (for pump wells), while surface waters were cleared of visible wastes before sample collection. Filtration of water samples was done in the in the field using $0.45 \mu \mathrm{m}$ diameter disposable filters to ensure the removal of suspended solids before storage in prepared bottles. Acidification of samples was done with $1.0 \mathrm{~mL}$ of conc. $\mathrm{HNO}_{3}$ using new syringes. This is necessary to prevent sorption. The samples were stored in ice packed containers to maintain the transportation temperature. Accordingly, before the sampling, sample bottles and beakers were washed thoroughly and soaked in distilled water acidified with $1.0 \mathrm{~mL}$ of $\mathrm{HNO}_{3}$ for 3 days. They were also rinsed with dilute $\mathrm{HNO}_{3}$ and vigorously rinsed at least three times with the water sources at the point of water collection. Samples for analysis were prepared using $2 \mathrm{ppm}, 5 \mathrm{ppm}$ and $10 \mathrm{ppm}$ standard solution (Agilent technology) for all the metals.

\section{Laboratory analysis}

Laboratory analysis for the concentration of $\mathrm{As}, \mathrm{Cr}^{3+}$, $\mathrm{Zn}^{2+}, \mathrm{Ni}^{2+}, \mathrm{Se}^{2+}, \mathrm{Pb}^{2+}, \mathrm{Cu}^{2+}, \mathrm{Hg}^{2+}, \mathrm{Cr}^{2+}, \mathrm{Ni}^{2+}, \mathrm{Cd}^{2+}$ and $\mathrm{Mn}^{2+}$ was done using Fast Sequential (FS) (Varian 2400 AA) atomic absorption spectrophotometer. Agilent FS2400AA has an accuracy level of $99.8 \%$ and precision of $97.6 \%$. Detection limits of the elements are shown in Tables 1 and 2. All sampling steps and data analysis were performed according to standard methods for water and wastewater APHA (1995).

\section{Data analysis}

Microsoft Excel and Suffer 11 software were used to show the distribution of the contaminants in the area. The results were discussed and compared with the World Health Organization (WHO) standards for water quality with respect to the associated health risk. Statistical tools like Student's $t$ test and Levene's test were applied to analyze the data. Student's $t$ test was applied to compare the element means difference between the pre-monsoon and post-monsoon seasons. Stating the hypothesis;

HO There is significant difference between the means concentration of chemical constituents in of the element in the pre-monsoon and post-monsoon season.

H1 There is no significant difference between the means of the element in the pre-monsoon and post-monsoon season. Levene's test was applied to check the homogeneity of variances of the samples.

\section{Result and discussion}

Results of hydrochemical analysis are presented in Tables 1 and 2 for pre-monsoon season and post-monsoon season, respectively. Table 3 is the summarized result with percentage measures above drinking-water limits.

\section{Levels of heavy metals and potential health effects}

Human activities like mining, to a large extent, upset the natural cycle of heavy metals and help increase their content in the various media to toxic levels. According to FDA (1987), IOM (2002), EPA (2003), the effects of heavy metals on humans depend on ingested dosage and may cause impairment to human health. Figure 3 shows the mechanism of heavy metal intoxication in humans.

The main threats to human health from heavy metals are associated with exposure to lead, cadmium, mercury and arsenic, Lars (2003). Concentration of heavy metals in rocks, water and soils spans across vast areas. Some of the heavy metals have no significant physical or biological action except for the toxic effects in relation to inhibiting the actions of certain enzymes Long et al. (1995). If they become excess, they become toxic and can lead to damage to the internal organs, reduce energy levels, mental and central nervous dysfunction, plants and aquatic lives are not left out Ayandiran and Dahunsi (2016). The effects of longterm exposure may result in slowly progressing physical, muscular and neurological degenerative processes Gerhat and Blomquist (1992).

Although medical records of the villagers were difficult to access to evaluate the incidences of the toxicity of these metals in the areas, personal discussions and observations show high incidences of abortion in women, selenoises in children and aged women, high level of mental disorders among the youth population and Parkinson diseases among old men and women, but a great number of them attribute these adverse health incidences to poisons from their enemies, witch doctors and inability to please their ancestors or the gods of their fore- fathers.

\section{$\mathrm{pH}$}

The $\mathrm{pH}$ of water samples of pre-monsoon (dry) season in the area ranges from 2.05 to 9.87 , while samples of post-monsoon (rainy) season ranged from 3.85 to 10.68 . Pre-monsoon season samples show that the surface waters are more acidic than groundwater. The $\mathrm{pH}$ of samples from mine sites, especially the active mines, ranged from 2.05 to 4.56 . This indicates that the water is highly acidic, especially in areas like Enyigba, Amorie, Ameka and Mkpuma Akpatakpa, where active mining is ongoing. This study also showed that the $\mathrm{pH}$ of water samples in the Enyigba areas is more acidic than 


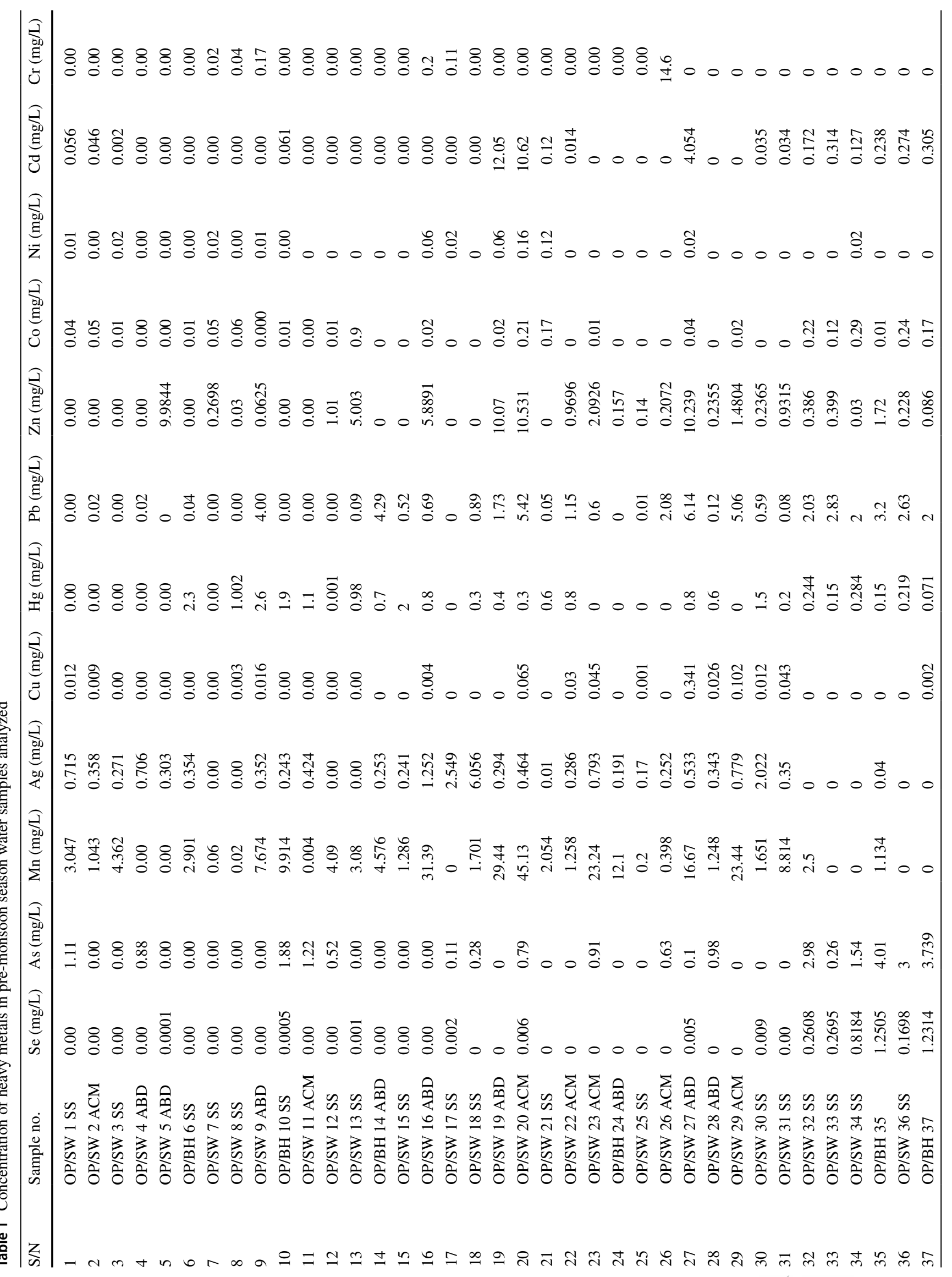




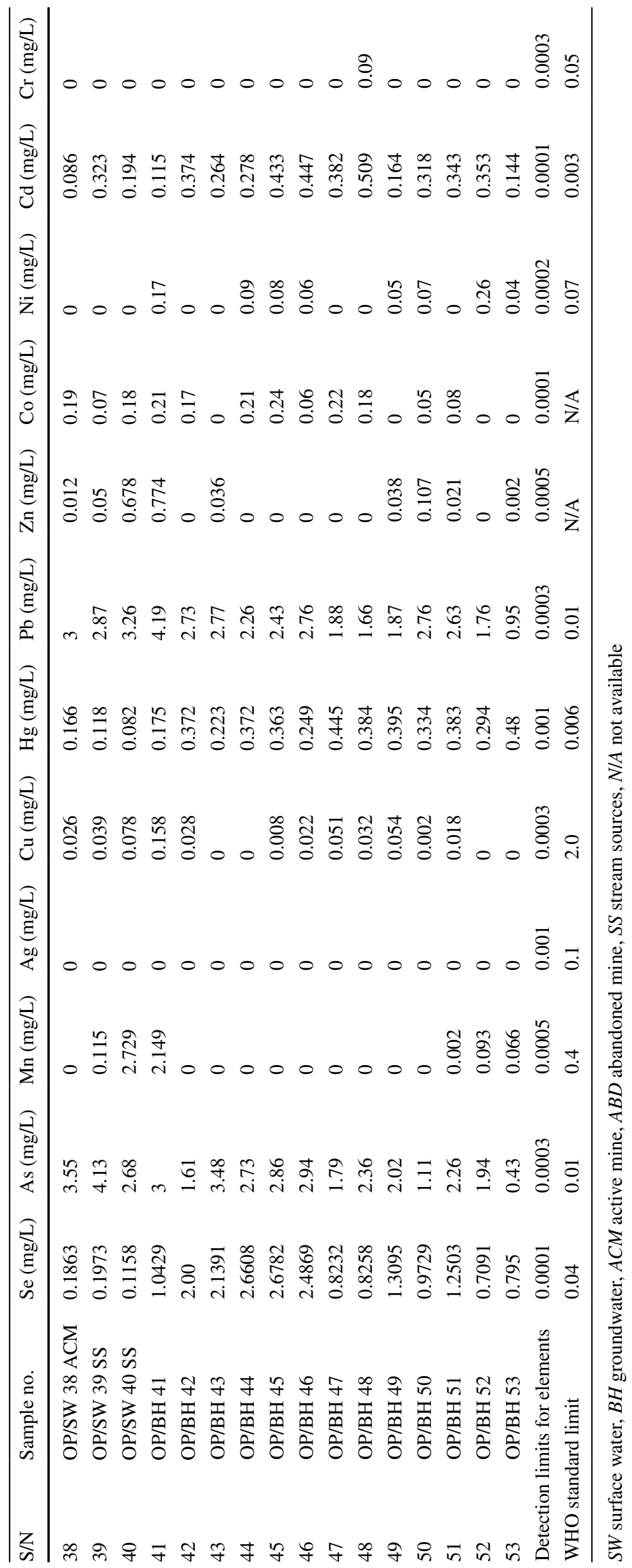




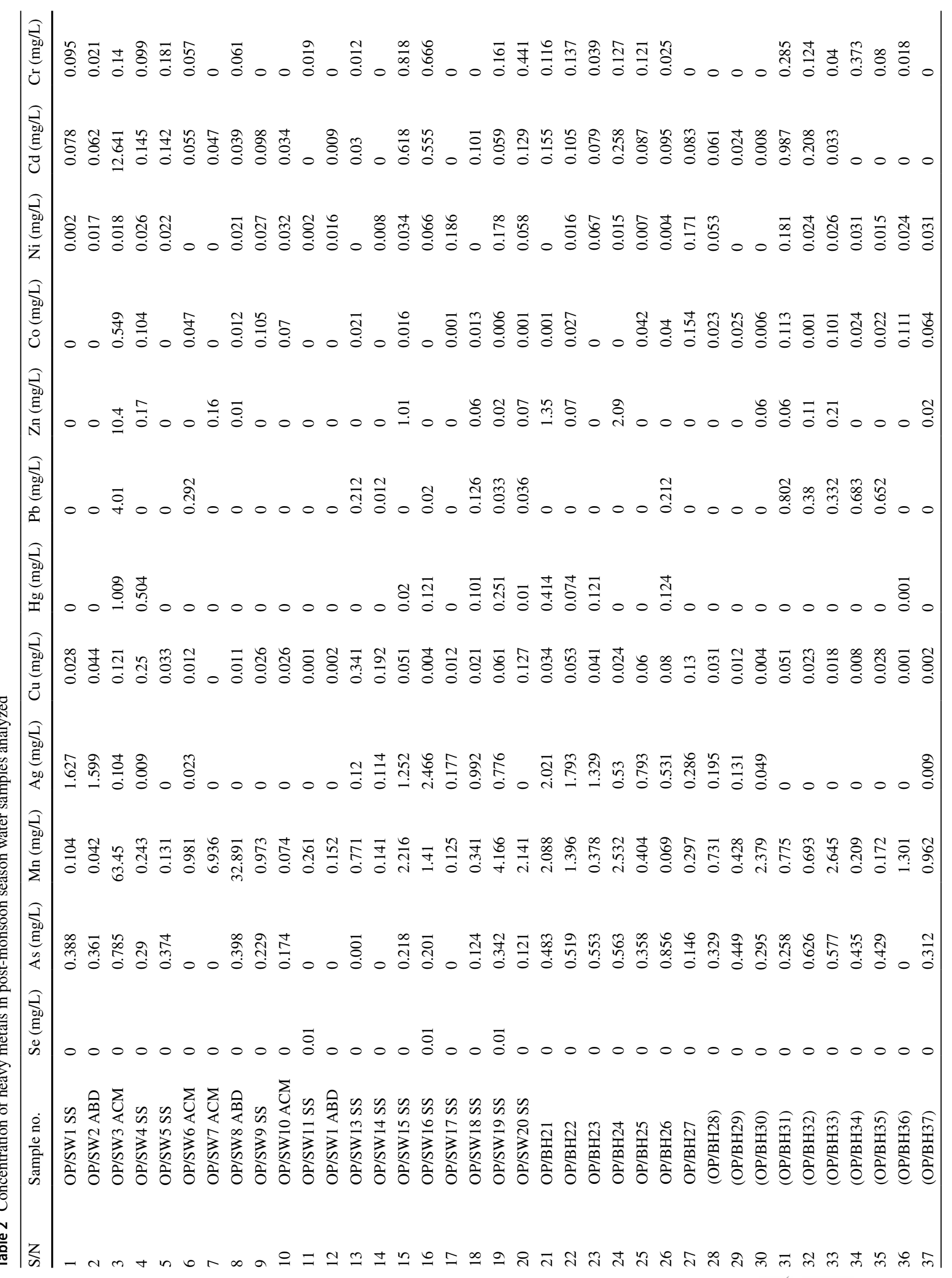


184 Page 8 of 23

Applied Water Science (2020) 10:184

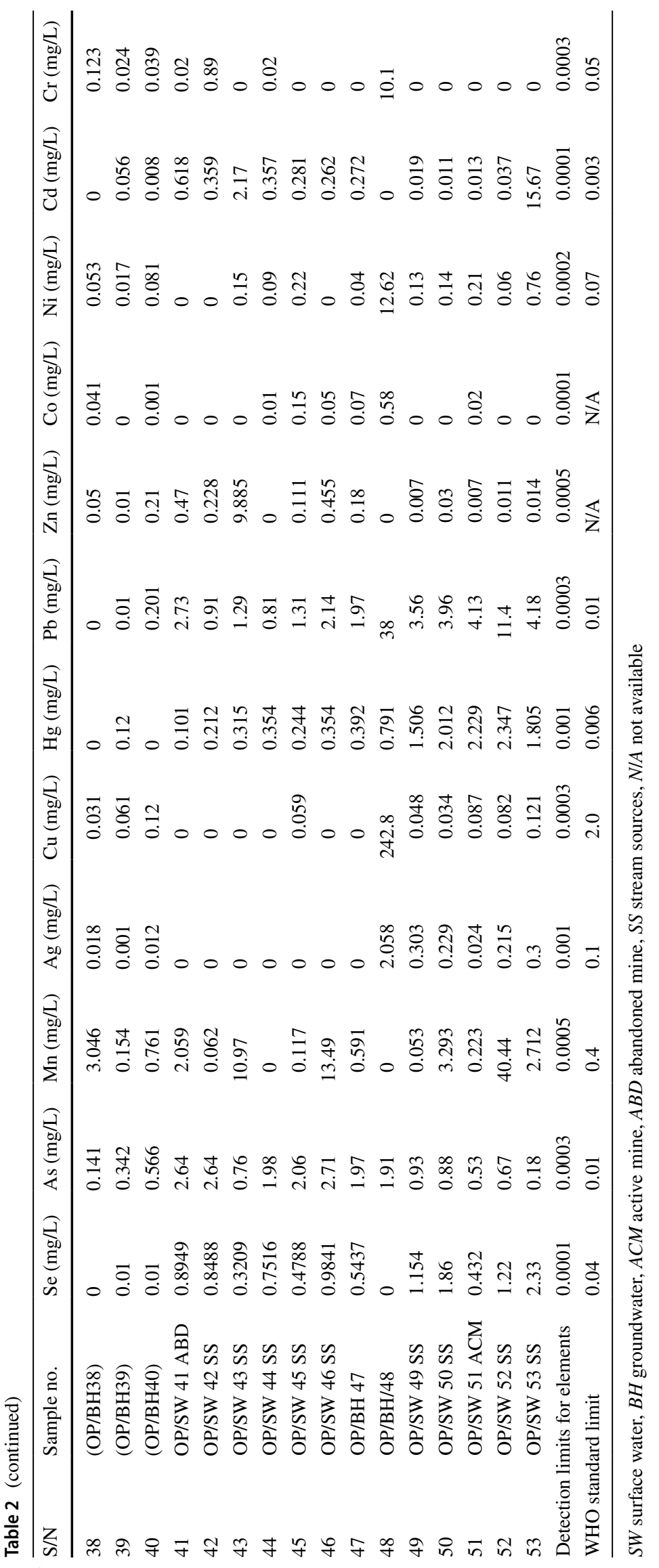

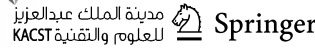




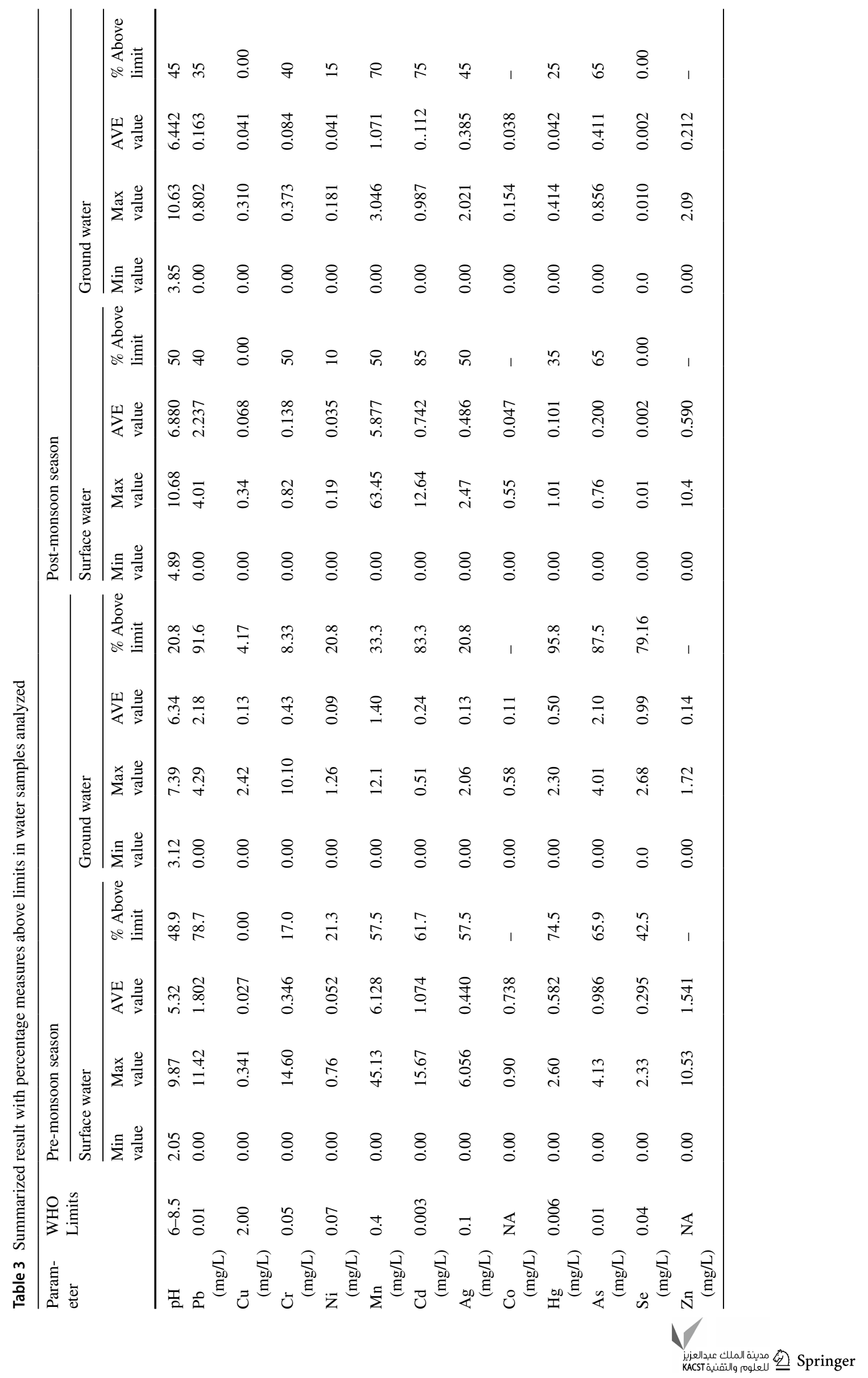


other mining areas of the Abakaliki area. Generally, the $\mathrm{pH}$ of water resources in the mining areas is not in line with the WHO guideline for drinking water, especially in rivers and streams closer to the mines where mine wastes have been reportedly discharged into. This acidity in the active mining areas can be attributed to the active chemical activities taking place in the area. This high acidity was observed in pre-monsoon season samples, it is very worrisome because this is the time when the villagers suffer shortage of water, and are left with no option than the use of the acidic water for their domestic purposes. Villages affected by this high acidity include Enyigba, Okpuitumo, Amanchara, Oganga, Ezza- Obia, Ameka, Mkpuma Akpatakpa, Onuzu and Okaria Agbaja. This can be due to the discharge of mine waters from active mines into adjoining streams and river channels in these areas.

\section{Lead}

The general population is exposed to lead from air and food in roughly equal proportions. Its occurrence and concentrations in drinking water is generally below $5 \mathrm{mg} / \mathrm{L}$, although much higher concentrations (above $100 \mathrm{mg} / \mathrm{L}$ ) have been measured where lead fittings are present Howard and Bartram (2003). Owing to the decreasing use of lead-containing additives in petrol and of lead-containing solder in the food processing industry, concentrations in air and food are declining, and intake from drinking water constitutes a greater proportion of total intake of lead Sawyer et al. (1998). Occupational exposure to inorganic lead occurs in mines and smelters as well as welding of lead painted metal, and in battery plants. Low or moderate exposure may take place in the glass industry. High levels of air emissions may pollute areas near lead mines and smelters. From the analysis, lead concentrations of pre-monsoon season water samples ranges between 0 (around Ndeguleke, Obeagu Ikenyi and Abakaliki urban) and $11.4 \mathrm{mg} / \mathrm{L}$, while post-monsoon season sample ranges from 0 to $4.01 \mathrm{mg} / \mathrm{L}$. This shows very high pollution (about $85 \%$ ) of lead for the water samples especially in the areas where active mining is ongoing. This result clearly indicates that the gangues and mine wastes of the lead ores (galena) significantly affect the quality of water sources of the area. Apart from the composition of these waste and gangues in the area, the low $\mathrm{pH}$, the salinity and presence of $\mathrm{CO}_{2}$ in the water sources cause faster dissolution of lead in water ATSDR (2007). Lead is very mobile in water especially, at low $\mathrm{pH}$. WHO (1984) proposed a health guideline value of $0.05 \mathrm{mg} / \mathrm{L}$ and in 1993 reviewed it to $0.01 \mathrm{mg} / \mathrm{L}$. This review was necessary on the basis that lead is a cumulative poison and that there should be no accumulation of body burden of lead. Davies et al. (2005) opined that the high concentration of lead in water of mining sites can be attributed to the high immobility of lead. The result shows higher concentration at the Mkpuma Akpatakpa area than other areas (Fig. 2).

Lead is a highly toxic metal whose widespread use has caused extensive environmental contamination and health problems in many parts of the world. The common symptom of contamination of lead is lead poisoning which displays as anemia because lead interferes with the formation of hemoglobin. It prevents iron uptake. Higher levels of lead may produce permanent brain damage and kidney dysfunction. Over time, lead will substitute $\mathrm{Ca}$ in bone which acts to store the lead. Then in old age, the lead is reactivated by slow dissolution of the bone Essa (1999). This can be attributed to the high rate of individuals with bone deformations as observed in the area. The symptoms of acute lead poisoning are headache, irritability, abdominal pain and various symptoms related to the nervous system. Lead encephalopathy is characterized by sleeplessness and restlessness. According to Lidsky and Schneider (2003), children may be affected by behavioral disturbances, learning and concentration difficulties. In severe cases of lead encephalopathy, the affected person may suffer from acute psychosis, confusion and reduced consciousness. People who have been exposed to lead for a long time may suffer from memory deterioration, prolonged reaction time and reduced ability to understand. Recent research by Mortada et al. (2001) has shown that long-term low-level lead exposure in children may also lead to diminished intellectual capacity. Acute exposure to lead is known to cause proximal renal tubular damage. Long-term lead exposure may also give rise to kidney damage. Engwa et al. (2018) noted that among others acute exposure of lead can cause loss of appetite, fatigue, sleeplessness, hallucinations, vertigo, renal dysfunction, hypertension and arthritis, while chronic exposure can result in birth defects, mental retardation, autism, psychosis, allergies, paralysis, weight loss, dyslexia, hyperactivity, muscular weakness, kidney damage, brain damage, coma and may even cause death.

\section{Copper}

Copper is both an essential nutrient and a drinking-water contaminant. Food and water are the primary sources of copper exposure in developed countries. Ores of copper are chalcopyrite $\left(\mathrm{CuFeS}_{2}\right)$, chalcocite $\left(\mathrm{Cu}_{2} \mathrm{~S}\right)$, covellite $(\mathrm{CuS})$, cuprite $\left(\mathrm{Cu}_{2} \mathrm{O}\right)$ and malachite $\left(\mathrm{CuCO}_{3} \cdot \mathrm{Cu}(\mathrm{OH})_{2}\right)$ (ATSDR 2007). Staining of laundry and sanitary wares occurs at copper concentrations above $1 \mathrm{mg} / \mathrm{L}$. Gallagher (2001) stated that at levels above $2.5 \mathrm{mg} / \mathrm{L}$ copper imparts an undesirable bitter taste to water; at higher levels, the color of water is also impacted. The WHO (2011) guidelines derived a provisional health-based guideline value of $2 \mathrm{mg} / \mathrm{L}$ for copper. From the analysis, copper values of pre-monsoon and postmonsoon season samples ranged from 0 to $0.341 \mathrm{mg} / \mathrm{L}$. Significant values were recorded at the active mines at Ameka, 

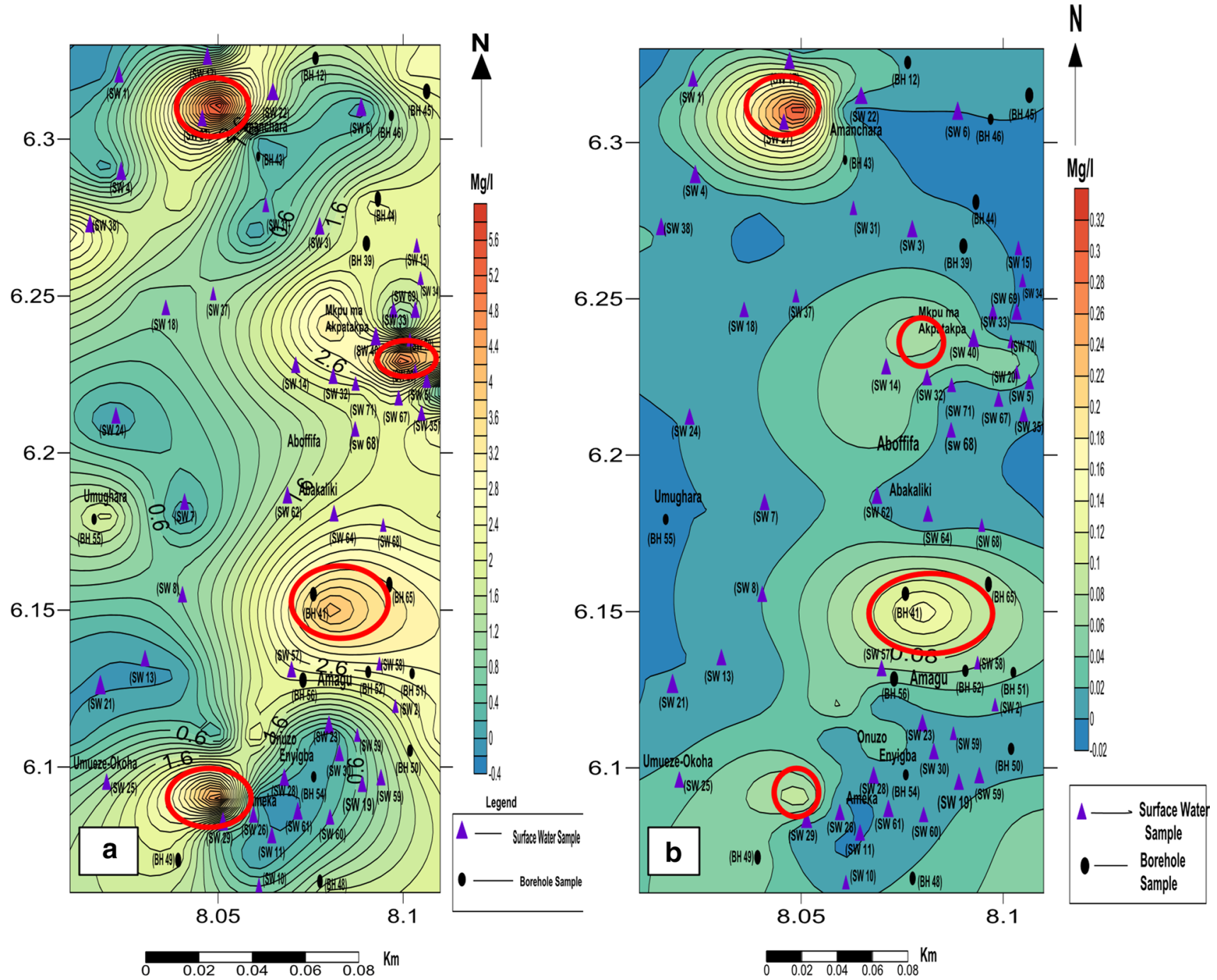

Fig. 2 Distribution of a lead $\mathbf{b}$ copper showing potentially high risk areas (as highlighted in red shapes)

Mkpuma Akpatakpa, Amanchara and surface water sources around Onuzu (Fig. 2). The result indicates that the concentration of copper $(100 \%)$ in the study area is below the WHO (2011) guideline for drinking water. Brikké (2000) noted that chalcopyrite (which is endowed in the area) breaks down into copper and pyrite, but copper has low mobility and reacts slowly with water. This can be attributed to the low concentration of copper in the area. Nriagu and Pacyna (1988) also stated that copper, on exposure to air and water, forms a thin protective metallic shield which reduces the surface area for reactivity.

Copper is essential for good health. However, exposure to higher doses can be harmful. Long-term exposure to copper dust can irritate your nose, mouth and eyes, and cause headaches, dizziness, nausea and diarrhea. If you drink water that contains higher than normal levels of copper, you may experience nausea, vomiting, stomach cramps or diarrhea.
Intentionally high intakes of copper can cause liver and kidney damage and even death. We do not know if copper can cause cancer in humans. EPA does not classify copper as a human carcinogen because there are no adequate human or animal cancer studies ATSDR (2004).

\section{Chromium}

Chromium is widely distributed in the Earth's crust. It can exist in valences of +2 to +6 . In general, food appears to be the major source of intake Jardine et al. (1999), Robson (2003). Chromium is highly carcinogenic; therefore, minimal intake has been advocated (WHO 2011). The analysis shows that concentrations of chromium in pre-monsoon season samples ranges between 0 and $14.6 \mathrm{mg} / \mathrm{L}$, while postmonsoon season samples range from 0 to $0.818 \mathrm{mg} / \mathrm{L}$. About $80 \%$ of the samples show no content for chromium, while the 
mines and the surrounding rivers around them show values above the WHO guideline of $0.05 \mathrm{mg} / \mathrm{L}$ especially at the Enyigba mine where it rose to $14.6 \mathrm{mg} / \mathrm{L}$ (Fig. 3). The area is composed of high grade igneous and baked shales, these can be the sources of chromium in the area. Studies show that the reduction of chromium (VI) to chromium (III) can occur under suitable conditions in the aqueous environment. According to Kimbrough et al. (1999), the most common reducing agents present in aqueous systems include: organic matter; hydrogen sulfide; sulfur, iron sulfide; ammonium; and nitrate. Saleh et al. (1989) also noted that the reduction half-life of chromium (VI) in water with soil and sediment ranged from 4 to 140 days, with the reaction typically occurring faster under anaerobic rather than aerobic conditions. Generally, the reduction of chromium (VI) to chromium (III) is also favored under acidic conditions Kimbrough et al. (1999). This is true as water sources recorded low pH in the area.
Chromium, in its hexavalent form, is the most toxic species of chromium though some other species such as Chromium (III) compounds are much less toxic and cause little or no health problems. Chromium (VI) has the tendency to be corrosive and also to cause allergic reactions to the body. Therefore, breathing high levels of chromium (VI) can cause irritation to the lining of the nose and nose ulcers. It can also cause anemia, irritations and ulcers in the small intestine and stomach, damage sperm and male reproductive system. The allergic reactions due to chromium include severe redness and swelling of the skin. Exposure of extremely high doses of chromium (VI) compounds to humans can result in severe cardiovascular, respiratory, hematological, gastrointestinal, renal, hepatic and neurological effects and possibly death Engwa et al. (2018).
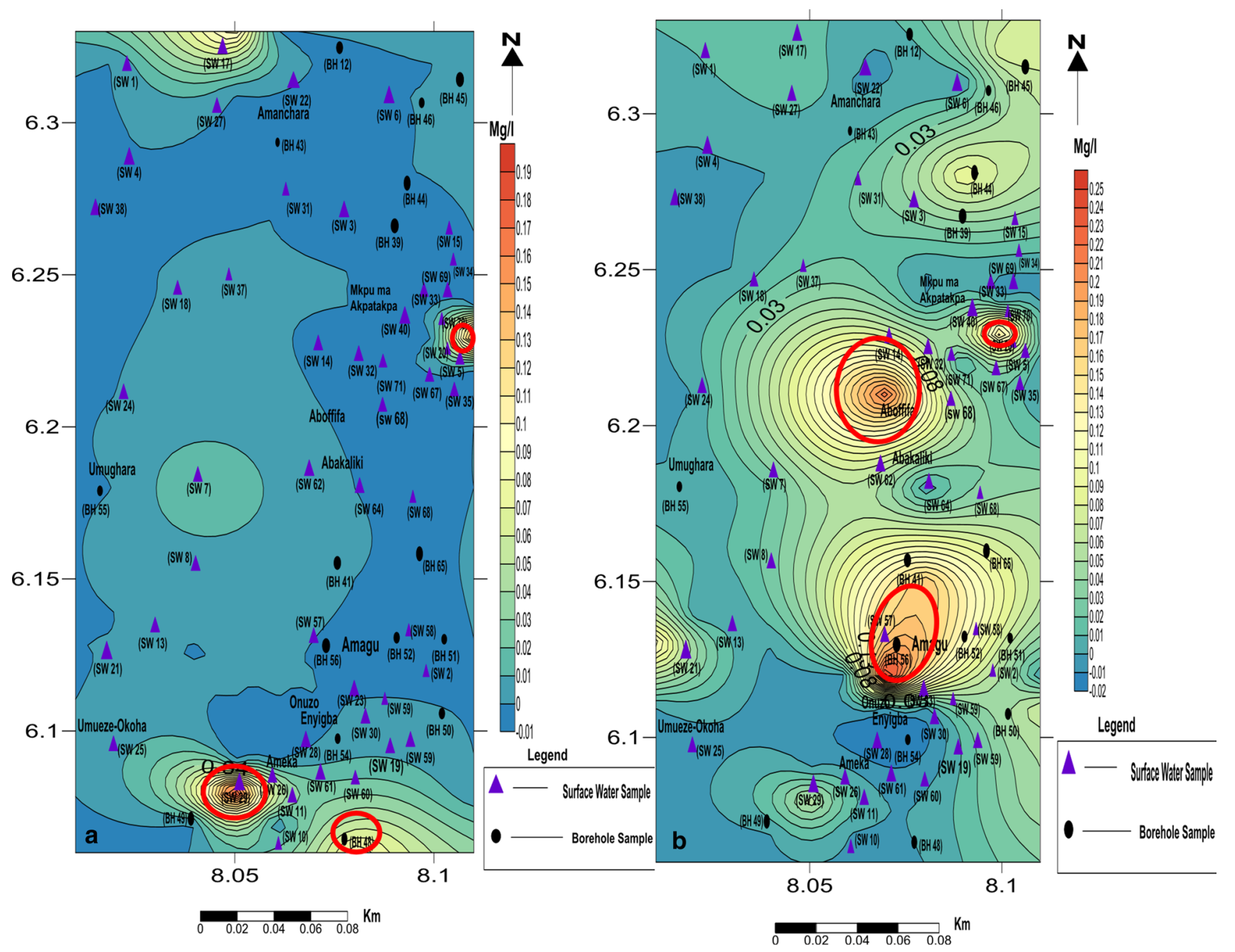

Fig. 3 Distribution of a chromium, b nickel showing potentially high risk areas (as highlighted in red shapes) 


\section{Nickel}

Nickel is noted in special cases of release from natural or industrial nickel deposits in the ground. It occurs naturally in water, with concentrations normally less than $0.02 \mathrm{mg} / \mathrm{L}$ WHO (2011). Food is the dominant source of nickel exposure in the non-smoking, non-occupationally exposed population, while water is generally a minor contributor to the total daily oral intake Aremu et al. (2002). The analysis shows concentrations of water samples in pre-monsoon season samples ranging from 0 to $1.26 \mathrm{mg} / \mathrm{L}$, while postmonsoon season samples range from 0 to $0.186 \mathrm{mg} / \mathrm{L}$. Only the distributaries of Ebonyi River show significant concentrations, especially around the mines of Enyigba (Fig. 3). But water samples within the mining areas are above the WHO (2011) guideline value of $0.07 \mathrm{mg} / \mathrm{L}$. This reflects high concentration for nickel. Sources of nickel in mining areas may include effluent water generated from mining and smelting operations, runoff from tailing piles, or from utility water used for mine operations ATSDR (2005). Mann et al. (1989) also indicated that tailing effluents from sulfidic ores are acidic due to the bacterial generation of sulfuric acid from the sulfidic minerals in the tailings, and very high concentrations of soluble nickel sulfate may be released. These discharges consist mostly of less-soluble silicates and sulfides that readily settle out Barcan (2002). Lucassen et al. (2002) also noted that the presence of iron-(di) sulfides in wetland sediments has been associated with increased mobilization of nickel into groundwater during periods of drought.

Nickel has an extensive range of carcinogenic mechanisms which include regulation of transcription factors, controlled expression of certain genes and generation of free radicals. Nickel has been shown to be implicated in regulating the expression of specific long non-coding ribonucleic acids (RNA). It has also been demonstrated that nickel can generate free radicals, which contributes to carcinogenic processes Engwa et al. (2018).

\section{Manganese}

Manganese is one of the most abundant metals in the Earth's crust, usually occurring with iron, oxygen, sulfur and chlorine ATSDR (2012). It is an essential element for humans and other animals and occurs naturally in food and water sources. Occurrence levels in fresh water typically range from 1 to $200 \mathrm{mg} / \mathrm{L}$, although levels as high as $10 \mathrm{mg} / \mathrm{L}$ in acidic groundwater have been reported; higher levels in aerobic waters usually associated with industrial pollution particularly in anaerobic or low oxidation conditions are also reported WHO (2011). The analysis shows that the concentration of manganese for pre-monsoon season samples ranges from $0 \mathrm{mg} / \mathrm{L}$ (in few places, especially in groundwater samples) to $45.13 \mathrm{mg} / \mathrm{L}$, while post-monsoon season samples ranges from 0.042 to $63.45 \mathrm{mg} / \mathrm{L}$. These high values were recorded in the active mines (Fig. 4). The abandoned mines, however, recorded high values up to $26.44 \mathrm{mg} / \mathrm{L}$. This result shows that water sources (especially mine pond water and groundwater) have higher values above the WHO (2011) guideline value of $0.4 \mathrm{mg} / \mathrm{L}$. This high concentration is attributed to the dissolution of manganese from the chalcopyrite and siderite ores which underlie the area. This is controlled by the solubility, $\mathrm{pH}$, Eh (oxidation-reduction potential) and the characteristics of the available anions in water Clewell et al. (2003). Aschner et al. (2007) emphasized that the metal may exist in water in any of four oxidation states; however, $\mathrm{Mn}(\mathrm{II})$ predominates in most waters ( $\mathrm{pH} 4-7)$, but may become oxidized under alkaline conditions at $\mathrm{pH}>8$ EPA (1984). The principal anion associated with $\mathrm{Mn}(\mathrm{II})$ in water is usually carbonate $\left(\mathrm{CO}_{3}^{2-)}\right.$ Schaanning et al. (1988). This increases the concentration as the carbonate composition of the shales is readily available for reaction.

Although manganese is an essential metal for the body, it recently became a metal of global concern when methylcyclopentadienyl manganese tricarbonyl (MMT), which was known to be toxic was introduced as a gasoline additive. MMT has been claimed to be an occupational manganese hazard and linked with the development of Parkinson's disease-like syndrome of tremour, gait disorder, postural instability and cognitive disorder. Exposure to elevated levels of manganese can result in neurotoxicity. Manganism is a neurological disease due to manganese characterized by rigidity, action tremour, a mask-like expression, gait disturbances, bradykinesia, micrographia, memory and cognitive dysfunction, and mood disorder. The symptoms of manganism are very similar to that of Parkinson disease.

\section{Cadmium}

Cadmium occurs naturally in the environment. Additional releases of cadmium to the environment occur from natural sources and from processes such as combustion of fossil fuel, incineration of municipal or industrial wastes, or land application of sewage sludge or fertilizer EPA (1985). WHO (2008) reveals that smoking is a significant additional source of cadmium exposure in humans. Occurrence levels in drinking water are usually less than $1 \mathrm{mg} / \mathrm{L}$ Elinder (1985). From the analysis, cadmium concentration in dry season samples ranges $0 \mathrm{mg} / \mathrm{L}$ (in very few places around Abakaliki and Odomoke) to $15.67 \mathrm{mg} / \mathrm{L}$, while rainy season samples ranges from 0 to $12.641 \mathrm{mg} / \mathrm{L}$.

Very high values were recorded around Mkpuma Akpatakpa mine $(15.67 \mathrm{mg} / \mathrm{L}$ and $10.62 \mathrm{mg} / \mathrm{L})$ and Amanku (12.05 mg/L) (Fig. 5). 80\% of the samples are above the WHO (2011), guideline value of $0.003 \mathrm{mg} / \mathrm{L}$ for drinking water. This is acute contamination. These high levels can be linked to the weathering and subsequent dissolution of the 


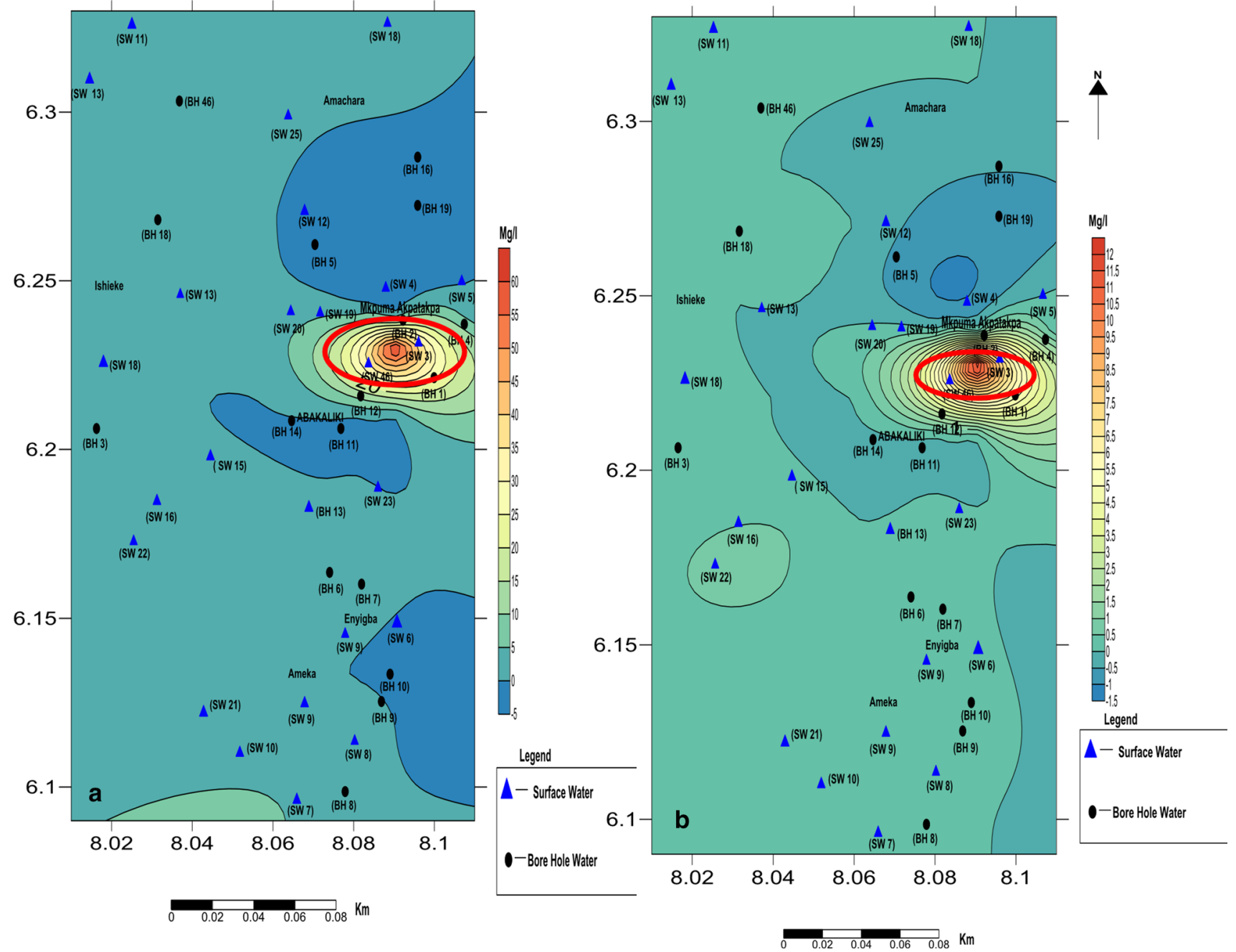

Fig. 4 Distribution of a manganese, $\mathbf{b}$ cadmium with potentially high risk areas (as highlighted in red shapes)

chalcopyrite and pyrite ores in the area. Cadmium's mobility in water depends on several factors including the $\mathrm{pH}$ and the availability of organic matter. Generally, cadmium will bind strongly to organic matter and this will, for the most part, immobilize cadmium Autier and White (2004). Cadmium in water tends to be more available when the $\mathrm{pH}$ is low (acidic) Elinder (1992).

Cadmium and its compounds have several health effects in humans. The health effects of cadmium exposure are exacerbated due to the inability of the human body to excrete cadmium. In fact, cadmium is re-absorbed by the kidney thereby limiting its excretion Pendias-Kabata and Pendias (1984). Cadmium is released as soluble $\mathrm{Cd}^{2+}$ ion during weathering. Also, toxicity of cadmium results from cadmium substitution for zinc in enzymes Stoessel (2004). The critical toxic endpoint after ingestion is kidney damage Davies et al. (2005), because of bio-accumulation in the liver and kidney. Cd poisoning may result in the $\mathrm{Cd}$ substitution for $\mathrm{Ca}$ in bones producing itaiitai, a degenerate bone disease. Further, this condition can cause bone mineralization as studies on animals and humans have revealed osteoporosis (skeletal damage) due to cadmium. Short-term exposure to inhalation of cadmium can cause severe damages to the lungs and respiratory irritation, while its ingestion in higher dose can cause stomach irritation resulting to vomiting and diarrhea. Long-term exposure to cadmium leads to its deposition in bones and lungs. As such, cadmium exposure can cause bone and lung damage. Cadmium is highly toxic to the kidney and it accumulates in the proximal tubular cells in higher concentrations. Thus, cadmium exposure can cause renal dysfunction and kidney disease. Also, cadmium exposure can cause disturbances in calcium metabolism, formation of renal stones and hypercalciuria. Cadmium is also classified as group 1 carcinogens for humans by the International Agency for Research on Cancer. 


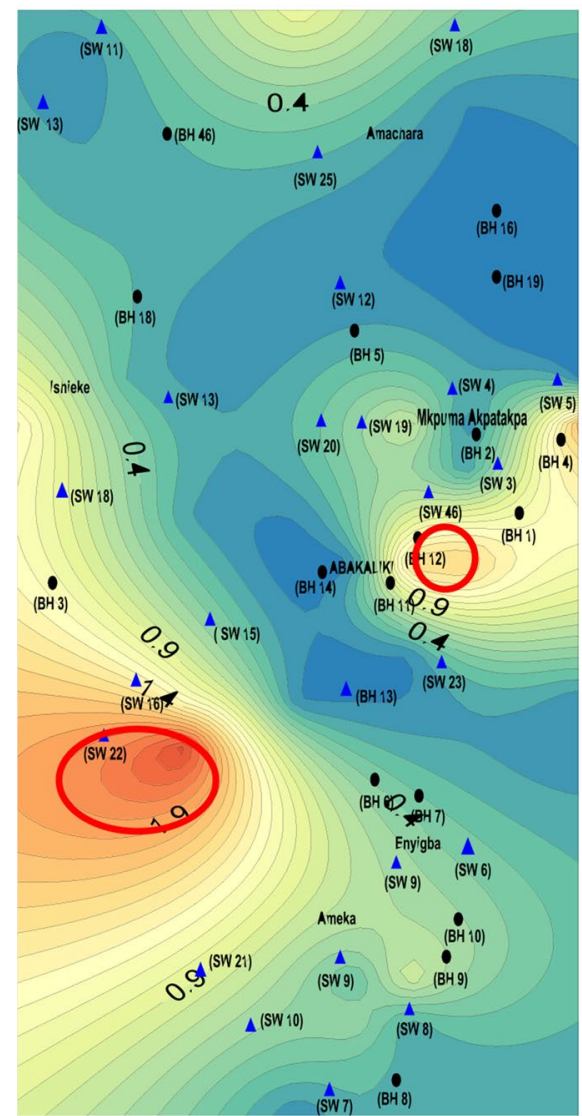

a

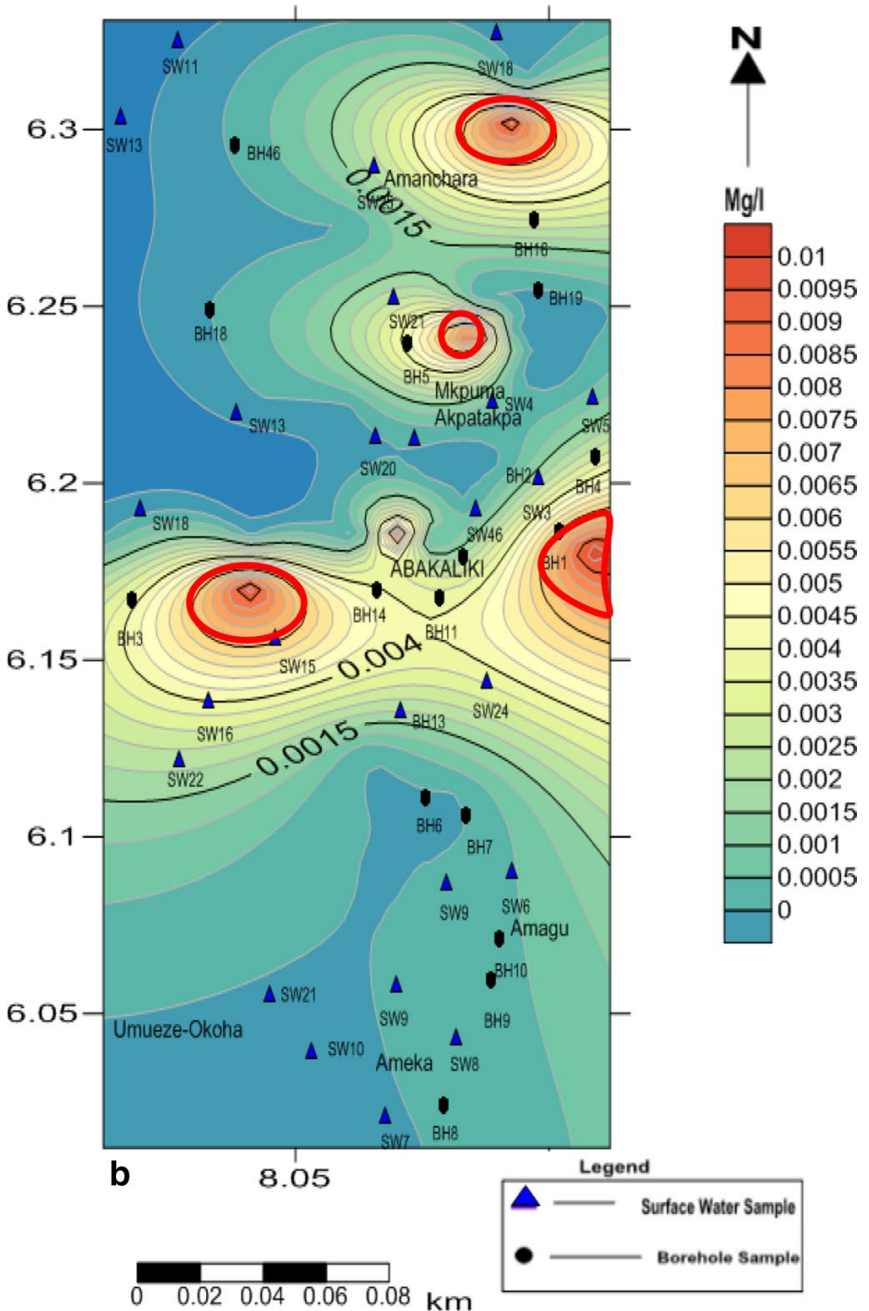

Fig. 5 Distribution of a silver, $\mathbf{b}$ selenium with potentially high risk areas (as highlighted in red shapes)

\section{Silver}

Concentration of silver in pre-monsoon season water samples ranged between 0 (in very many places) and $6.056 \mathrm{mg} / \mathrm{L}$, while post-monsoon season samples ranged from 0 to $2.466 \mathrm{mg} / \mathrm{L}$. Over $50 \%$ of samples showed concentrations above the WHO (2011) guideline of $0.1 \mathrm{mg} / \mathrm{L}$. These high concentrations were not recorded in the mines, but around the waste dumping areas of Umuaghara (the central waste dump of Abakaliki metropolis), Isieke and Umuezekoha. Although Lindsay and Sadiq (1979) stated that emissions from smelting operations, manufacture and disposal of certain photographic and electrical supplies, coal combustion and cloud seeding are some of the anthropogenic sources of silver in the biosphere, the principal sources of silver are the ores of copper, copper-nickel, lead, and lead-zinc Sparks (2005). This high concentration can be attributed to the decomposition of wastes from the dumps. Also, since silver in soils is largely immobilized by precipitation to insoluble salts and by complexation or adsorption by organic matter, the concentration can be localized and silver may be leached into groundwater from the soils. The leaching rate increases with low $\mathrm{pH}$ and increases drainage ATSDR (1990), Smith and Carson (1977). This is true as over $60 \%$ of water samples recorded very low $\mathrm{pH}$ in the area. Lucassen et al. (2002) noted that the availability of free silver in marine environments is strongly controlled by salinity, because of the affinity of silver for the chloride ion.

The only sign of silver overload is argyria, a condition in which skin and hair are heavily discolored by silver in the tissues WHO (2008).

\section{Mercury}

From the analysis, concentration of mercury in pre-monsoon season samples ranged from 0 to $2.647 \mathrm{mg} / \mathrm{L}$, while postmonsoon season samples ranged from 0 to $1.004 \mathrm{mg} / \mathrm{L}$. This indicates high level of contamination of mercury in the water 
sources of the area (especially around the Mkpuma Akpatakpa, Amanchara and Ameka mining areas) (Fig. 6), over $60 \%$ of the samples are above the WHO (2011) guideline of $0.006 \mathrm{mg} / \mathrm{L}$ for drinking water. Normal breakdown of minerals in rocks and soil can occur from exposure to wind and water, and from volcanic activity in the area ATSDR (2009), this can be linked to this high concentration in the area. Human activities, since the start of the industrial age (e.g., mining, burning of fossil fuels), have resulted in additional release of mercury to the environment Dikinya and Areola (2010). Mercury associated with soils can be directly washed into surface waters during rain events. According to Meili (2013), surface runoff is an important mechanism for transporting mercury from soil into surface waters, particularly for soils with high humic content. This is pertinent in the Abakaliki area since the soil is rich in humus. Gilmour and Henry (1991) also noted that the most common organic form of mercury, methylmercury, is soluble, mobile, and quickly enters water by dissolution. Low $\mathrm{pH}$ and high mercury sediment concentrations favor the formation of methylmercury, which has greater bioavailability potential for aquatic organisms than inorganic mercury compounds WHO (2011).
Mercury is considered the most toxic heavy metal in the environment. Its poisoning is referred to as acrodynia or pink disease. Mercury is an element that can easily combine with other elements to form inorganic and organic mercury. Exposure to elevated levels of metallic, inorganic and organic mercury can damage the kidney, brain and developing fetus, while methyl mercury is highly carcinogenic. Organic mercury is lipophilic in nature and thus can easily penetrate cell membranes. Mercury and its compound affects the nervous system, and thus, increased exposure of mercury can alter brain functions and lead to tremors, shyness, irritability, memory problems and changes in hearing or vision. Short-term exposure to metallic mercury vapors at higher levels can lead to vomiting, nausea, skin rashes, diarrhea, lung damage, high blood pressure, etc., while short-term exposure to organic mercury poisoning can lead to depression, tremors, headache, fatigue, memory problems, hair loss, etc. Since these symptoms are also common in other illness or disease conditions, diagnosis of mercury poisoning may be difficult in such cases. Chronic levels of mercury exposure can lead to erethism, a disease condition characterized by
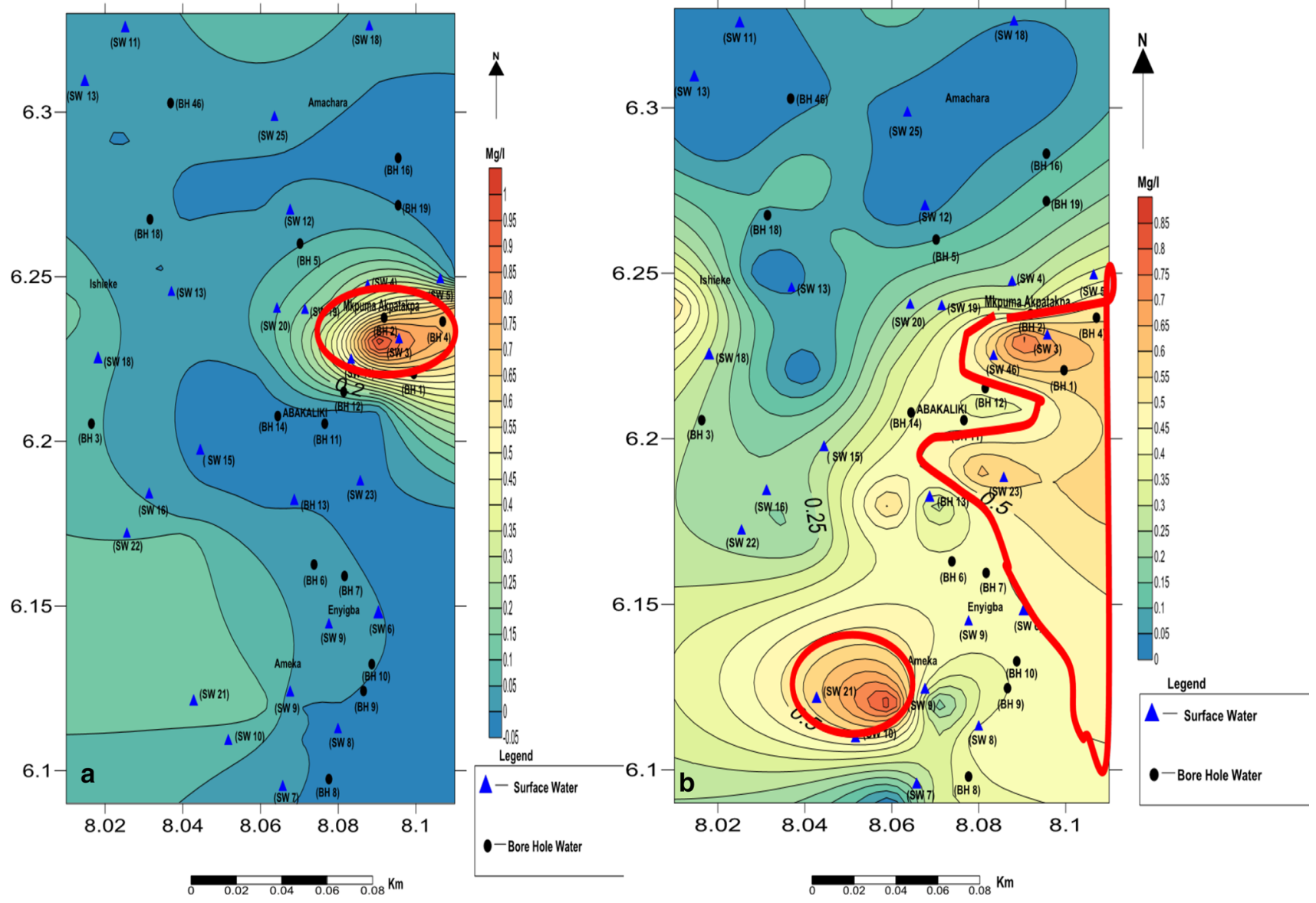

Fig. 6 Distribution of a mercury, $\mathbf{b}$ arsenic showing potentially high risk areas (as highlighted with red shapes) 
excitability, tremor of the hands, memory loss, timidity, and insomnia.

\section{Arsenic}

Arsenic contaminations have occurred as a result of both natural geologic processes and the activities of man. Anthropogenic sources of arsenic include human activities such as mining and processing of ores. Result of analysis shows concentration of $0 \mathrm{mg} / \mathrm{L}$ (in few places) to $4.13 \mathrm{mg} / \mathrm{L}$ for pre-monsoon season samples, while post-monsoon season samples ranged from 0 to $0.856 \mathrm{mg} / \mathrm{L}$, with groundwater recording higher concentrations (Fig. 6). This result shows that about $86 \%$ of the samples have values above the WHO (2011) guideline of $0.01 \mathrm{mg} / \mathrm{L}$ for drinking water. This is high potential health risk especially around the Mkpuma Akpatakpa mining area, Akpara River, Enyigba, Ngele River Enyigba, Enyigba salt Lake and Ameka Pond. This emanates from the dissolution of ores. Arsenic is associated with ores containing metals, such as copper and lead; volcanic eruptions are another source of arsenic ATSDR (2007). Arsenic is found widely in the earth's crust often as sulfides or metal arsenides or arsenates. In water, it is mostly present as arsenate, but in anaerobic conditions, it is likely to be present as arsenite Almela et al. (2002). It is usually present in natural waters at concentrations of less than 1-2 mg/L. However, in waters, particularly ground waters, where there are sulfide mineral deposits and sedimentary deposits deriving from volcanic rocks, the concentrations can be significantly elevated up to $12 \mathrm{mg} / \mathrm{L}$ WHO (2011). Arsenic is found in the diet, particularly in fish and shellfish, in which it is found mainly in the less toxic organic form Garvey et al. (2013). Soluble forms move with the water and may be carried long distances through rivers EPA (1979).

Lower levels of arsenic exposure can cause nausea and vomiting, reduced production of erythrocytes and leukocytes, abnormal heart beat, pricking sensation in hands and legs, and damage to blood vessels. Long-term exposure can lead to the formation of skin lesions, internal cancers, neurological problems, pulmonary disease, peripheral vascular disease, hypertension and cardiovascular disease and diabetes mellitus Smith et al. (2000). Other effects might include decreased production of red and white blood cells, which may cause fatigue, abnormal heart rhythm, blood-vessel damage resulting in bruising and impaired nerve function causing a "pins and needles" sensation in your hands and feet ATSDR (2007). Chronic arsenicosis results in many irreversible changes in the vital organs, and the mortality rate is higher. In spite of the magnitude of this potentially lethal toxicity, there is no effective treatment for this disease Mazumder (2008). Perhaps the single-most characteristic effect of long-term oral exposure to inorganic arsenic is a pattern of skin changes. These include patches of darkened skin and the appearance of small "corns" or "warts" on the palms, soles, and torso, and are often associated with changes in the blood vessels of the skin. These skin patches were observed on two men at Ikenyi, but on interaction, they attributed it to old age. Skin cancer may also develop. Swallowing arsenic has also been reported to increase the risk of cancer in the liver, bladder, and lungs. The Department of Health and Human Services DHHS (1995) has determined that inorganic arsenic is known to be a human carcinogen. The International Agency for Research on Cancer IARC $(1980,2004)$ has determined that inorganic arsenic is carcinogenic to humans. EPA (2005) also has classified inorganic arsenic as a known human carcinogen.

\section{Selenium}

Result of the analysis shows that the concentration of selenium for pre-monsoon season samples ranges from 0 to $2.6956 \mathrm{mg} / \mathrm{L}$, while post-monsoon season samples ranged from 0 to $0.01 \mathrm{mg} / \mathrm{L}$. This indicates high degree of contamination as about $60 \%$ of the samples (especially groundwater) are above the WHO (2011) drinking-water standard of $0.04 \mathrm{mg} / \mathrm{L}$. These high values were observed around the Mkpuma Akpatakpa and Amachara mining areas, and water sources around the Isieke and Umuaghara waste dump sites. Selenium is also commonly found in rocks and soils, often in association with sulfur-containing minerals, or with silver, copper, lead and nickel minerals.

ATSDR (2003). Apart from its dissolution from the sulfur-rich ores and migration from decomposed wastes.

ATSDR (2003) the high concentration can be linked to chemical behavior of selenium. Recent studies including Engwa et al. 2018 and Garvey et al. 2013 has shown that selenium compounds that can dissolve in water are sometimes very mobile, and surface waters can receive selenium from the atmosphere by dry and wet deposition, from adjoining waters that may contain selenium, from surface runoff, and from subsurface drainage.

Selenium can cause muscle tenderness, tremor, lightheadedness, facial flushing, blood clotting problems, liver and kidney problems, and other side effects. High doses of selenium can cause significant side effects including nausea, vomiting, nail changes, loss of energy and irritability. Poisoning from long-term use is similar to arsenic poisoning, with symptoms including hair loss, white horizontal streaking on fingernails, nail inflammation, fatigue, irritability, nausea, vomiting, garlic breath odor and a metallic taste.

\section{Zinc}

Result of the analysis for the pre-monsoon season water samples ranged from 0.00 (in most places) to $10.53 \mathrm{mg} / \mathrm{L}$, while post-monsoon season samples ranged from 0 to 
$10.42 \mathrm{mg} / \mathrm{L}$. Although WHO (2011) does not state a permissible limit for zinc, concentration between 3 and $5 \mathrm{mg} / \mathrm{L}$ is good for healthy living ATSDR (2007). This result indicates that only about $10 \%$ of the samples are polluted. The high values were observed strictly in the mining sites and mine ponds of Amanchara, Mkpuma Akpatakpa, Enyigba and Ameka (Fig. 7). Zinc is abundant in the earth's crust. It is a chalcophile metallic element and forms several minerals, including sphalerite $(\mathrm{ZnS})$, the commonest $\mathrm{Zn}$ mineral, smithsonite $\left(\mathrm{ZnCO}_{3}\right)$ and zincite $(\mathrm{ZnO})$, but is also widely dispersed as a trace element in pyroxene, amphibole, mica, garnet and magnetite Andrews and Sutherland (2004). It is released to the environment from both natural and anthropogenic sources; however, releases from anthropogenic sources are greater than those from natural sources Barbera et al. (1991). Apart from the dissolution of zinc in water, which increases with acidity, zinc is immobile in water Gundersen and Steinnes (2003). In water, zinc occurs primarily in the +2 oxidation state, it dissolves in acids to form hydrated $\mathrm{Zn}$ cations and in strong bases to form zincate anions, which are hydroxo complexes, e.g., - 2- 2-( $\left.\mathrm{Zn}[\mathrm{OH}]_{3}\right),\left(\mathrm{Zn}[\mathrm{OH}]_{4}\right)$, and $\left(\mathrm{Zn}[\mathrm{OH}]_{4}\left[\mathrm{H}_{2} \mathrm{O}\right]_{2}\right)$ Fuhrer (1986).

Toxicity in human may occur if zinc concentration approaches $400 \mathrm{mg} / \mathrm{kg}$ and $3 \mathrm{mg} / \mathrm{L}$ in soil and water, respectively. This is characterized by symptoms of irritability, muscular stiffness and pain, loss of appetite and nausea. Zinc appears to have a protective effect against the toxicities of both cadmium and lead Fergusson (1990). Zn has been shown to exert adverse reproductive biochemical, physiological and behavioral effect on a variety of aquatic organisms as concentrations exceed $20 \mathrm{mg} / \mathrm{kg}$. Toxicity is, however, influenced by many factors such as the temperature, hardness and $\mathrm{pH}$ of the water WHO (2011).

\section{Cobalt}

Cobalt is a naturally occurring element that has properties similar to those of iron and nickel. Small amounts of cobalt are naturally found in most rocks, soil, water, plants and animals, typically in small amounts. Cobalt is also found in meteorites Barceloux (1999). However, cobalt is usually found in the environment combined with other elements
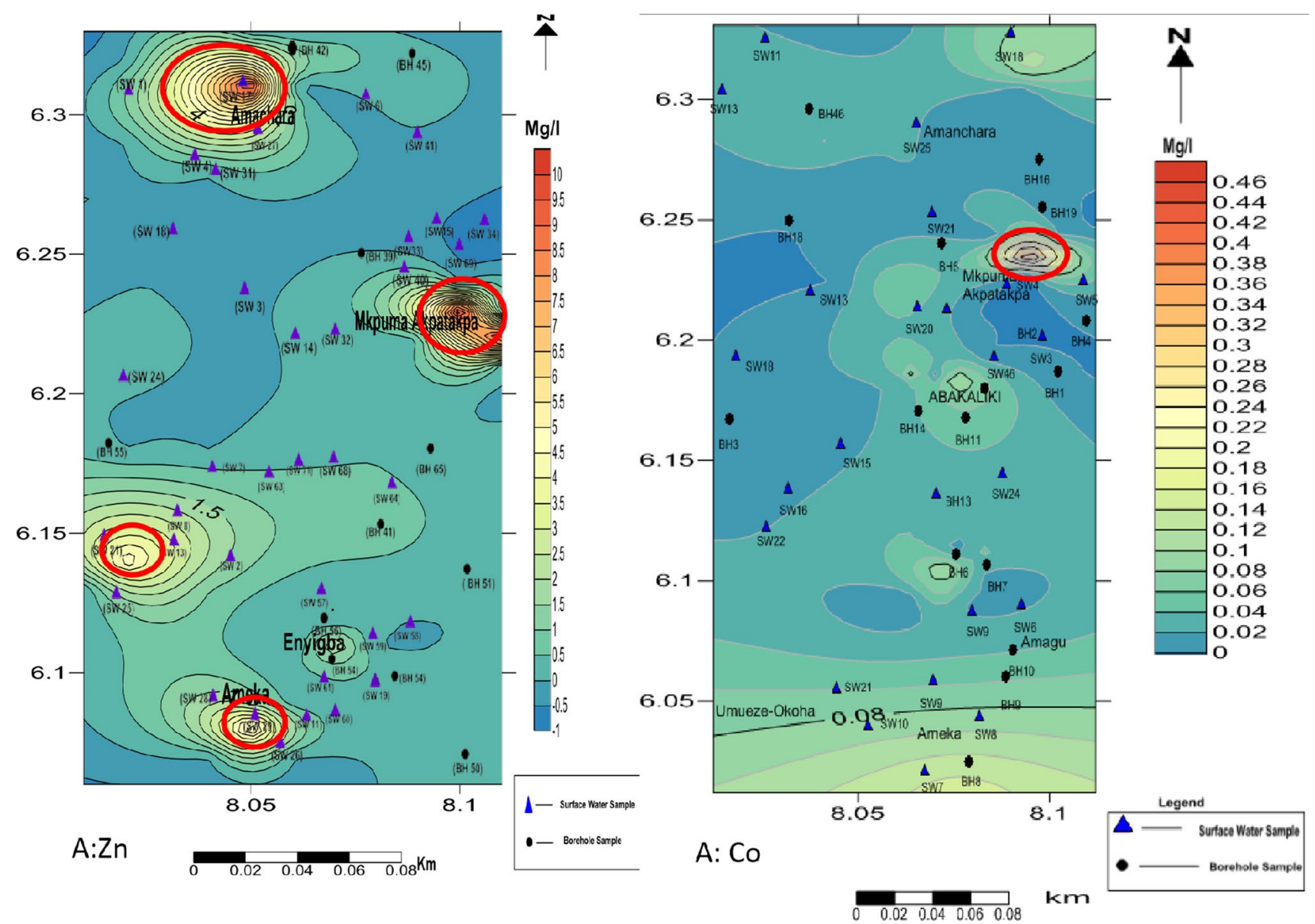

Fig. 7 Distribution of a zinc, b cobalt showing potentially high risk areas (as highlighted in red shapes) 
such as oxygen, sulfur and arsenic. The result shows low concentrations of cobalt in water samples analyzed. Premonsoon season samples ranged from 0 (about 74\% samples) to $0.9 \mathrm{mg} / \mathrm{L}$, while post-monsoon season ranged from 0 to $0.549 \mathrm{mg} / \mathrm{L}$ (Fig. 7). Although no permissible limit has been established for cobalt WHO (2011), cobalt is highly radioactive ATSDR (2004), and high concentration can pose serious health risk. The result shows significant concentration around Mkpuma Akpatakpa mines and Umuaghara dump site. This can be linked to mining and weathering of volcanic rocks in the area. Acidity and redox potential have an effect on the behavior of cobalt in water. The adsorption of cobalt by particulate matter decreases with decrease in $\mathrm{pH}$, since the increasing $\mathrm{H}^{+}$concentration competes with metal binding sites Andreev and Simenov (1990).

ATSDR (2004) noted that high levels of cobalt can lead to breathing problems including asthma, pneumonia and wheezing. Lower exposures may cause skin rashes, nausea and vomiting, while long-term exposures may lead to diarrhea, bleeding, coma and even death. Radioactive cobalt is carcinogenic and causes damages to cells including skin blisters and burns, hair loses and temporal sterility.

\section{Student's $\boldsymbol{t}$ test and Levene's test}

Calculated value of $t(0.4539)$ is less than the critical (or tabulated) value of $t$ at $d f 11$, i.e., $0.4539<2.201$; hence, the Ho is accepted. There is therefore a significant difference between the means concentration of chemical constituents of the element in the pre-monsoon and post-monsoon season (see Table 4).

Using Levenes' test to check the homogeneity of variances of the samples. A value less than 0.05 means that the variability in the pre-monsoon and post-monsoon season is not the same. That the variance in the pre- monsoon does vary more than the variance in the post-monsoon condition; thus, there is significant difference between the means of the element in the pre-monsoon and post-monsoon season (see Table 5).

\section{Public health implications of metal pollution}

Humans are exposed to heavy metals through various ways including food and water consumption, inhalation of polluted air, skin contact and most importantly, by occupational exposure at workplace. Though some heavy metals are essential for certain biochemical and physiological activities in the body, elevated level in the body can have deleterious health defects. Most heavy metals are generally toxic to the body at very low level. Lead, arsenic, cadmium and mercury are carcinogenic; and pose serious public health safety issues. Lead causes serious environmental contamination and health problems. Lead poisoning, which is a major 
Table 5 Levenes' test for variance homogeneity

\begin{tabular}{lllllllll}
\hline & Means & Variance & Standard dev. & Observation & $d f$ & $t$ test & $F$ & Sig. \\
\hline Var 1 & 0.944583 & 18.6070813 & 1.691553 & 12 & 14 & -0.4549 & 0.707 & 0.078 \\
Var 2 & 1.131901 & 26.31877 & 2.119889 & 12 & 14 & & & \\
\hline
\end{tabular}

public health problem displays as anemia because lead interferes with the formation of hemoglobin and prevents iron uptake. Brain damage and kidney dysfunction have also been attributed to high levels of lead, arsenic, cadmium and mercury. Lead has been known to substitute $\mathrm{Ca}$ in bone which acts to store the lead. Then in old age, the lead is reactivated by slow dissolution of the bone Essa (1999). This can be attributed to the high rate of individuals with bone deformations as observed in the area. Copper contamination can cause public health nuisance like irritation of the nose, mouth, and eyes. Headaches, dizziness, nausea, vomiting and diarrhea have also been attributed to higher levels of copper, while severe cardiovascular, respiratory, hematological, gastrointestinal, renal, hepatic and neurological effects have been linked to high chromium Engwa et al. (2018). Nickel has also been implicated in the carcinogenic process, and radioactive cobalt is carcinogenic and can cause damage to cells apart from breathing problems including asthma, pneumonia and wheezing. In the other hand, manganism and Parkinson disease have been linked to high levels of manganese. Osteoporosis (skeletal damage) and severe damages to the lungs and respiratory irritation resulting to vomiting and diarrhea are indicative of cadmium contamination. Silver overload presents a public health condition in which skin and hair are heavily discolored by silver in the tissues (argyria), WHO (2008).

\section{Conclusion}

Levels of heavy metals in water resources and the potential health risk have been studied in the mining areas of Abakaliki. This includes local communities of Enyigba, Ameka, Ameri, Amorie, Amanchara and Mkpuma Akpatakpa where mining has been ongoing for over three to five decades. One hundred and six water samples were collected and analyzed using Atomic Absorption Spectrophotometric and ultraviolet/visible spectroscopic method. Suffer 11 was used to plot the distribution of the metals in the area to show potentially high risk areas. Result shows the levels $\mathrm{Pb}^{2+}>\mathrm{Hg}^{2+}$ $>\mathrm{As}^{2+}>\mathrm{Cd}^{2+}>\mathrm{Mn}^{2+}>\mathrm{Ag}^{2+}>\mathrm{Se}^{2+}>\mathrm{Ni}^{2+}>\mathrm{Cr}^{2+}>\mathrm{Cu}^{2+}$ in the area. Ameka and Mkpuma Akpatakpa mining areas recorded higher concentrations of the geochemical constituents than other communities. Acidic to slightly basic waters exists for the areas, while the abandoned mines showed considerably lower concentrations than the active mines. Water sources around active mines are polluted and hence considered unfit for many domestic and agricultural uses, especially for drinking and feeding of live stocks. This is because bio-accumulation can occur in the food chain. Lead, cadmium, mercury and arsenic are highly carcinogenic and can cause serious public health problems. Nickel, manganese and cobalt cause cells damages and affect carcinogenic processes. Heavy metal toxicity could be acute, while others could be chronic after long-term exposure which may lead to the damage of several organs in the body such as the brain, lungs, liver and kidney causing diseases in the body. Alternative sources of water supply including sitting of boreholes (after accurate geochemical surveys) for potable water for the community dwellers should be facilitated. Meanwhile, sensitization and awareness of the health risk of the consumption of mine tailings affected water sources should be carried out intensively through all possible channels especially in the local dialect of the villagers.

Acknowledgements The authors are grateful to Professor T. U. Onuegbu of Department of Industrial Chemistry, Nnamdi Azikiwe University for reviewing this paper in the early drafts. We thank David Okeke of Springboard Research Laboratory, Awka, for his assistance in the analytical processes. We also appreciate our past students who gainfully assisted in the collection of samples and laboratory analysis. We thank Ovu Samuel and Obasi Victor for typesetting and running some of the statistical and computer programmes. The first author is grateful to Professor A. U. Okoro for his encouragements and mentorship.

Open Access This article is licensed under a Creative Commons Attribution 4.0 International License, which permits use, sharing, adaptation, distribution and reproduction in any medium or format, as long as you give appropriate credit to the original author(s) and the source, provide a link to the Creative Commons licence, and indicate if changes were made. The images or other third party material in this article are included in the article's Creative Commons licence, unless indicated otherwise in a credit line to the material. If material is not included in the article's Creative Commons licence and your intended use is not permitted by statutory regulation or exceeds the permitted use, you will need to obtain permission directly from the copyright holder. To view a copy of this licence, visit http://creativecommons.org/licenses/by/4.0/.

\section{References}

Abraham MR, Susan TB (2017) Water contamination with heavy metals and trace elements from Kilembe copper mine and tailing sites in Western Uganda; implications for domestic water quality. Chemosphere 169:281-287

Agency for Toxic Substances and Disease Registry (ATSDR) (1990) Toxicological profile for Copper U.S. Department of Health and 
Human Services, Public Health Service, Division of Toxicology 1600, Atlanta, GA 30333

Agency for Toxic Substances and Disease Registry (ATSDR) (2003) Toxicological profile for Nickel U.S. Department of Health and Human Services, Public Health Service, Division of Toxicology 1600, Atlanta, GA 30333

Agency for Toxic Substances and Disease Registry (ATSDR) (2004) Toxicological profile for Cobalt.U.S. Department of Health and Human Services, Public Health Service, Division of Toxicology 1600, Atlanta, GA 30333

Agency for Toxic Substances and Disease Registry (ATSDR) (2005) Toxicological profile for Nickel U.S. Department of Health and Human Services, Public Health Service, Division of Toxicology 1600, Atlanta, GA 30333

Agency for Toxic Substances and Disease Registry (ATSDR) (2007) U.S. Department of Health and Human Services, Public Health Service, Division of Toxicology 1600, Atlanta, GA 30333

Agency for Toxic Substances and Disease Registry (ATSDR) (2009) Toxicological profile for mercury. U.S. Department of Health and Human Services, Public Health Service, Division of Toxicology 1600, Atlanta, GA 30333

Agency for Toxic Substances and Disease Registry (ATSDR) (2012) Toxicological profile for Chromium U.S. Department of Health and Human Services, Public Health Service, Division of Toxicology 1600, Atlanta, GA 30333

Alexakis D (2016) Human health risk assessment associated with Co, $\mathrm{Cr}, \mathrm{Mn}, \mathrm{Ni}$ and $\mathrm{V}$ contents in agricultural soils from a Mediterranean site. Arch Agron Soil Sci 62(3):359-373

Almela C, Algora S, Benito V (2002) Heavy metal, total arsenic, and inorganic arsenic contents of algae food products. J Agric Food Chem 50:918-923

America Public Health Association (1995) Standard methods for the examination of water and waste water, 20th edn. American Public Health Association, Washington DC

Andreev G, Simenov V (1990) Distribution and correlation of elements in waters, suspensions, sediments and marine organisms from the Black Sea. Toxicol Environ Chem 28:1-9

Andrews S, Sutherland RA (2004) $\mathrm{Cu}, \mathrm{Pb}$ and $\mathrm{Zn}$ contamination in Nuuanu watershed, Oahu, Hawaii. Sci Total Environ 324(1-3):173-182

Aremu DA, Olawuyi J, Meshitsuka S (2002) Heavy metal analysis of groundwater from Warri, Nigeria. Int J Environ Health Res 12:261-267

Aschner M, Guilarte TR, Schneider JS (2007) Manganese: recent advances in understanding its transport and neurotoxicity. Toxicol Appl Pharmacol 221:131-147

Autier V, White D (2004) Examination of cadmium sorption characteristics for aboreal soil near Fairbanks, Alaska. J Hazard Mater 106B:149-155

Ayandiran TA, Dahunsi SO (2016) Toxicological assessment of fish (Clarias gariepinus) from polluted Oluwa River, Nigeria. Environ Monit Assess 188:1-18

Ayandiran TA, Ayandele AA, Dahunsi SO, Ajala OO (2014) Microbial assessment and prevalence of antibiotic resistance in polluted Oluwa River, Nigeria. Egyptian J Aquat Res 40:291-299

Barbera R, Farre R, Mesado D (1991) Determination of cadmium, cobalt, copper, iron, lead, manganese, nickel and zinc in diets: development of a method. Nahrung 35(7):683-687

Barcan V (2002) Nature and origin of multicomponent aerial emissions of the copper-nickel smelter complex. Environ Int 28:451-456

Barceloux DG (1999) Zinc. Clin Toxicol 37(2):279-292

Blowes D, Ptacek C, Jambor J, Weisener C (2003) The geochemistry of acid mine drainage. Treatise Geochem 9:149-204

Brikké F (2000) Operation and maintenance of rural water supply and sanitation systems: a training package for managers and planners. Delft, IRC International Water and Sanitation Centre; and Geneva, World Health Organization

Burke KC, Dessawvagia RFJ, Whiteman AW (1972) Geology history of the Benue Valley and adjacent area, Africa geology, University of Ibadan Press. Geology 10(5):187-206

Buzatu A, Dill H-G, Buzgar N, Damian G, Maftei A-E, Apopei A-I (2016) Efflorescent sulfates from Baia Sprie mining area (Romania)_acid mine drainage and climatological approach. Sci Total Environ 542:629-641

Cidu R, Frau F, Da Pelo S (2011) Drainage at abandoned mine sites: natural attenuation of contaminants in different seasons. Mine Water Environ 30:113-126

Clewell HJ, Lawrence GA, Calne DB (2003) Determination of an occupational exposure guideline for manganese using the benchmark method. Risk Anal 23(5):1031-1046

Davies BE, Bowman C, Davies TC, Sellinus O (2005) Medical geology: perspectives and prospects. Essent Med Geol, Elsevier Inc., pp 1-14

DHHS (1995) Report to Congress on workers' home contamination study conducted under the workers' family protection act (29 U.S.C. 671a). Cincinnati, OH: U.S. Department of Health and Human Services, Public Health Service, Centers for Disease Control and Prevention, National Institute for Occupational Safety and Health. Pub no. 95-123. PB96192000

Dikinya O, Areola O (2010) Comparative analysis of heavy metal concentration in secondary treated waste irrigated soil cultivated by different crops. Int J Environ Sci Technol 7(2):337-346

ElAmari K, Valera P, Hibti M, Pretti S, Marcello A, Essarraj S (2014) Impact of mine tailings on surrounding soils and ground water: case of Kettaraold mine, Morocco. J Afr Earth Sci 100:437-449

Elinder CG (1985) Cadmium: uses, occurrence and intake. In: Friberg L, Elinder CG, Kjellström T (eds) Cadmium and health: a toxicological and epidemiological appraisal, vol I. Exposure, dose, and metabolism. Effects and response. CRC Press, Boca Raton, pp 23-64

Elinder CG (1992) Cadmium as an environmental hazard. IARC Sci Publ 118:123-132

Engwa GA, Ferdinand PU, Nwalo FN, Unachukwu MN (2018) Mechanism and effects of heavy metal toxicity in humans, poisoning in the modern world-new tricks for an old dog? Ozgur Karcioglu and Banu Arslan, IntechOpen. https://doi. org/10.5772/intechopen.82511

Environmental Protection Agency (EPA) (1979) Water-related environmental fate of 129 priority pollutants. U.S. Environmental Protection Agency, Office of Water Planning and Standards, Washington, DC. (EPA) 440479029a

Environmental Protection Agency (EPA) (1984) Health assessment document for manganese. Final draft. U.S. Environmental Protection Agency, Office of Research and Development, Cincinnat. (EPA) 600883013F

Environmental Protection Agency (EPA) (1985) Chemical identitymanganese, tricarbonyl methylcyclopentadienyl. U.S. Environmental Protection Agency, Office of Toxic Substances, Cincinnati

Environmental Protection Agency (EPA) (2003) Effluent guidelines and standards. General provisions. Toxic pollutants. Washington D.C. U.S EPA.40 CFR 401. 15

Environmental Protection Agency (EPA) (2005) Emissions of arsenic compounds. In: Technology Transfer Network. National Air Toxics Assessment. Pollutant-Specific Data Tables. US

Essa (1999) Agency for Toxic Substances and Disease Registry (ATSDR) (2007). U.S. Department of Health and Human Services, Public Health Service, Division of Toxicology 1600, Atlanta, GA 30333 
Equeenuddin MD, Tripathy S, Saho PK, Panigrahi MK (2010) Hydrogeochemical characteristics of acid mine drainage and water pollution at Makum Coalfield, India. J Geochem Explor 105:75-82

FDA (1987) U.S. Food and Drug Administration, code of federal regulations. 21 CFR 73. 199.21 CFR 73. 2991

Fergusson IE (1990) The heavy elements chemistry, environmental impact and health effects. Pergamon press, New York

Freeze RA, Cherry JA (1976) Groundwater water assessment. PrenticeHall, Englewood Cliffs, pp 248-261

Fuhrer GJ (1986) Extractable cadmium, mercury, copper, lead, and zinc in the lower Columbia River estuary, Oregon and Washington. In: U.S. Geological Survey water-resources investigations report. Portland

Gallagher CH (2001) Biochemical and pathological effects of copper deficiency. In: Nriagu JO (ed) Copper in the environment. Wiley, New York, pp 57-82

Gamvroula D, Alexakis D, Stamatis G (2013) Diagnosis of groundwater quality and assessment of contamination sources in the Megara basin (Attica, Greece). Arab J Geosci 6(7):2367-2381. https://doi.org/10.1007/s12517-012-0533-6

Garvey GJ, Hahn G, Lee RV (2013) Heavy metal hazards of Asian traditional remedies. Int J Environ Health Res 11(1):63-71

Gerhat JM, Blomquist JD (1992) Selected trace elements and organic contaminant in stream bed sediments of the Potomac River Basin. In: U.S. Geological Survey, Water Resources Investigation Report 95 - 4267, pp 1-12

Gilmour CC, Henry EA (1991) Mercury methylation in aquatic systems affected by acid deposition. Environ Pollut 71(2-4):131-169

Gundersen P, Steinnes E (2003) Influence of $\mathrm{pH}$ and TOC concentration on $\mathrm{Cu}, \mathrm{Zn}, \mathrm{Cd}$, and $\mathrm{Al}$ speciation in rivers. Water Res $37: 307-318$

Hakkou R, Benzaazoua M, Bussiere B (2008) Acid mine drainage at the abandoned Kettara Mine (Morocco): 1. Environmental characterization. Mine Water Environ 27:145-159

Han Y-S, Youm S-J, Oh C, Cho Y-C, Ahn J-S (2017) Geochemical and ecotoxicological characteristics of stream water and its sediments affected by acid mine drainage. Catena 148(1):52-59

Hartman HL (1992) SME mining engineering handbook. Society for Mining, Metallurgy, and Exploration Inc., Littleton, CO, p 3

Howard G, Bartram J (2003) Domestic water quantity, service level and health. World Health Organization, Geneva

IARC (1980) Arsenic and arsenic compounds. In: IARC monographs on the evaluation of the carcinogenic risk of chemicals to humans, Vol 23. Some metals and metallic compounds. International Agency for Research on Cancer, Lyon, pp 39-141

IARC (2004) Overall evaluations of carcinogenicity to humans: as evaluated in IARC monographs volumes 1-82 (at total of 900 agents, mixtures and exposures). International Agency for Research on Cancer, Lyon

Iloeje NP (1979) A new geography of Nigeria. Revised New Edition, pp 32-45

IOM (2002) Dietary reference intake of vit A, vit K, arsenic, chromium, copper, iodine, iron, manganese, molybdenum, nickel, silicon, vanadium, and zinc. Institute of Medicine, food and nutrition board, NRC. National Academy Press, Washington DC, pp 442-501

Jardine PM, Fendorf SE, Mayes MA (1999) Fate and transport of hexavalent chromium in undisturbed heterogeneous soil. Environ Sci Technol 33(17):2939-2944

Khalil A, Hanich L, Bannari A, Zouhri L, Pourret O, Hakkou R (2013) Assessment of soil contamination around an abandoned mine in a semi-arid environment using geochemistry and geostatistics: prework of geochemical process modeling with numerical models. J Geochem Explor 125:117-129
Khan S, Cao Q, Zheng YM, Haung YZ, Zhu YG (2008) Health risks of heavy metals in contaminated soils and food crops irrigated with wastewater in Beijing, China. Environ Pollut 152:686-692

Khan S, Rehman S, Khan AZ, Khan MA, Shah MT (2010) Soils and vegetables enrichment with heavy metals from geological sources in Gilgit, Northern Pakstan. Ecotoxicol Environ Saf 73:1820-1827

Kimbrough DE, Cohen Y, Winer AM (1999) A critical assessment of chromium in the environment. Crit Rev Environ Sci 29(1):1-46

Kogbe CA (1976) Palegeographic history of Nigeria from Albian times. In: Kogbe CA (ed) Geology of Nig. Elizabeth Publishers, Lagos, pp 237-252

Koki IB, Bayero AS, Umar A, Yusuf S (2015) Health risk assessment of heavy metals in water, air, soil and fish. Afr J Pure Appl Chem 9(11):204-210

Lars J (2003) Hazards of heavy metal contamination. Br Med Bull 68(1):167-182. https://doi.org/10.1093/bmb/ldg032

Lidsky I, Schneider JS (2003) Lead neurotoxicity in children: basic mechanisms and clinical correlates. Brain 126:5-19

Lindsay WL, Sadiq M (1979) Theoretical solubility relationships of silver in soils. In: Klein DA (ed) Environmental impacts of artificial ice nucleating agents. Dowden, Hutchinson, and Ross, Inc., Stroudsburg

Lucassen E, Smolders AJP, Roelofs JGM (2002) Potential sensitivity of mines to drought, acidification and mobilization of heavy metals: the sediment $\mathrm{S} / \mathrm{Ca}+\mathrm{Mg}$ ) ratio as diagnostic tool. Environ Pollut 120:635-646

Mann H, Fyfe WS, Kerrich R (1989) Retardation of toxic heavy metal dispersion from nickel-copper mine tailings, Sudbury district, Ontario: role of acidophilic microorganisms. I. Biological pathway of metal retardation. Biorecovery 1:155-172

Martinez-Martinez S, Acosta JA, Fascano A, Carnoma DM, Zornoza $R$, Cerda C (2013) Assessment of the lead and zinc content in natural soils and tailing ponds from the Cartagana-La Union mining district SE Spain. J. Geochem Explor 124:166-175

Mazumder G (2008) Chronic arsenic toxicity \& human health. Indian J Med Res 128(4):436-447

Meili M (2013) The coupling of mercury and organic matter in the biogeochemical cycle - towards a mechanistic model for the boreal forest zone. Water Air Soil Pollut 56:333-347

Mohammad AH, Bhuiyan MA, Samuel BD, Parvez L, Shigeyuki S (2010) Evaluation of hazardous metal pollution in irrigation and drinking water systems in the vicinity of a coal mine area of northwestern Bangladesh. J. Hazard Mater 179:1065-1077

Moreno-Jimenez E, Penalosa JM, Manzano R, Carpena-Riuz RO, Gamarra R, Esteban E (2009) Heavy metals distribution in soils surrounding an abandoned mine in NW Madrid Spain and their transference to wideflora. J Hazard Mater 162:854-859

Mortada WI, Sobh MA, El-Defrawy MM, Farahat SE (2001) Study of lead exposure from automobile exhaust as a risk for nephrotoxicity among traffic policemen. Am J Nephrol 2001(21):274-279

Moye J, Picard-Lesteven T, Zouhri L, El Amari K, Hibti M, Benkaddour A (2017) Groundwater assessment and environmental impact in the abandoned mine of Kettara (Morocco). Environ Pollut 231(Pt 1):899-907

Musah SN, Maxiwel A, Boateng A (2013) Health risks of heavy metals in selected crops cultivated in small-scale- gold- mining areas in Wassa- Amenfiwest district of Ghana. J Nat Sci Res 3(5):2224-3186

Nriagu JO, Pacyna JM (1988) Quantitative assessment of worldwide contamination of air, water and soils by trace metals. Nature 333:134-139

Nwachukwu SO (1975) Temperature of formation of vein, minerals in the south portion of the Benue Trough, Nigeria. J Min Geol 11(1 and 2):44-55 
Nwajide CS (2013) Geology of Nigeria's sedimentary basins. CSS Bookshops Limited, Lagos

Obage GN (2009) Geology and mineral resources of Nigeria. Springer, Dord Heidelberg

Obasi PN, Akudinobi BEB (2015) Geochemical assessment of heavy metal distribution and pollution status in soil/stream sediment in the Ameka mining area of Ebonyi state, Nigeria. Afr J Geosci Res 3(4):01-07

Obasi PN, Akudinobi BEB (2019a) Pollution status of arable soil and stream sediment in the mining areas of Abakaliki, Lower Benue Trough. Springer-Int J Environ Sci Technol. https://doi. org/10.1007/s13762-019-02337-z

Obasi PN, Akudinobi BEB (2019b) Heavy metals occurrence, assessment and distribution in water resources in the lead-zinc mining areas of Abakaliki, Southeastern Nigeria. Springer-Int J Environ Sci Technol. https://doi.org/10.1007/s13762-019-02489-y

Obiora SC, Chukwu A, Toteu SF, Davies TC (2016) Assessment of heavy metals contamination in soils around $\mathrm{Pb}-\mathrm{Zn}$ mining areas in Enyigba, Southeastern Nigeria. J Geol Soc India 87:453-462

Obiora SC, Chukwu A, Toteu SF, Davies TC (2018) Contamination of the potable water supply sources in the lead-zinc mining communities of Enyigba, Southeastern Nigeria. Mine Water Environ. https://doi.org/10.1007/s10230-018-0550-0

Owor M, Hartwig T, Muwanga A, Zachmann D, Pohl W (2007) Impact of tailings from the Kilembe copper mining district on lake George, Uganda. Environ Geol 51:1065-1075

Pendias-Kabata A, Pendias H (1984) Trace elements in soil and plants, 3rd edn. CRC Press, Boca Raton

Robson M (2003) Methodologies for assessing exposures to metals: human host factors. Ecotoxicol Environ Saf 56:104-109

Saleh FY, Parkerton TF, Lewis RV (1989) Kinetics of chromium transformations in the environment. Sci Total Environ 86:25-41

Sawyer R, Simpson-Hébert M, Wood S (1998) PHAST step-by-step guide: a participatory approach for the control of diarrhoeal disease. World Health Organization, Geneva (WHO/EOS/98.3)

Schaanning M, Naes K, Egeberg PK (1988) Cycling of manganese in the permanently anoxic Drammens field. Mar Chem 23:365-382

Shuai-Long W, Xiang-Rong X, Yu-Xin S, Jin-Ling L, Hua-Bin L (2013) Heavy metal pollution in coastal areas of south China: a review. Mar Pollut Bull 76:7-15

Smith IC, Carson BL (1977) Trace metals in the environment, vol 2. Silver. Ann Arbor Science Publishers, Inc., Ann Arbor

Smith AH, Lingas EO, Rahman M (2000) Contamination of drinkingwater by arsenic in Bangladesh: a public health emergency. Bull World Health Organ 78(9):1093-1103

Sparks DL (2005) Toxic metal in the environment: the role of surface. J Miner Soc Am 193-197
Stoessel (2004) Concentration of heavy metals in soils around mine sites in china lake province. J Environ Sci 3(24):230-244

Todd DK (1980) Groundwater hydrology, 2nd edn. Willey, New York

U.S. Bureau of Mines (1994) Proceedings of the international land reclamation and mine drainage conference and 3rd international conference on the abatement of acidic drainage: U.S. Bureau of Mines. Special Publication, SP 06D-94

World Health Organization (WHO) (1984) Guidelines for drinking water quality. World Health Organization, Geneva, pp 99-102

World Health Organization (WHO) (2008) Guidelines for drinking water quality, 3rd edn. WHO, Geneva

World Health Organization (WHO) (2011) Guidelines for drinking water quality, 3rd edn. World Health Organization, Geneva

Yousefi M, Saleh HN, Mohammadi AA, Mahvi AH, Ghadrpoori M, Suleimani H (2017) Data on water quality index for the groundwater in rural area Neyshabur county, Razavi province, Iran. Data Brief 15(2017):901-907

Zarborski PMP (1988) Upper Creataceous ammonite from Calabar region, South-east Nigeria. Bull Br Mus Net Hist (Geol) 39:1-72

Zhao C, Hobbs BE, Ord A, Peng S, Mühlhaus HB, Liu L (2004) Theoretical investigation of convective instability in inclined and fluid-saturated three-dimensional fault zones. Tectonophysics 387:47-64

Zhao C, Hobbs BE, Ord A, Hornby P, Peng S, Liu L (2007) Mineral precipitation associated with vertical fault zones: the interaction of solute advection, diffusion and chemical kinetics. Geofluids $7: 3-18$

Zhao C, Hobbs BE, Ord A (2008a) Convective and advective heat transfer in geological systems. Springer, Berlin

Zhao C, Hobbs BE, Hornby P, Ord A, Peng S, Liu L (2008b) Theoretical and numerical analyses of chemical-dissolution front instability in fluid-saturated porous rocks. Int J Numer Anal Methods Geomech 32:1107-1130

Zhao C, Hobbs BE, Ord A (2010) Theoretical analyses of nonaqueous-phase-liquid dissolution induced instability in two-dimensional fluid-saturated porous media. Int J Numer Anal Methods Geomech 34:1767-1796

Zhiyuan L, Zongwei M, Tsering JV, Zengwei Y, Lei H (2014) A review of soil heavy metal pollution from mines in China: pollution and Health risk assessment. Sci Total Environ 468(469):843-853

Publisher's Note Springer Nature remains neutral with regard to jurisdictional claims in published maps and institutional affiliations. 